\title{
The plasmin-antiplasmin system: structural and functional aspects
}

\author{
Johann Schaller • Simon S. Gerber
}

Received: 13 April 2010/Revised: 3 September 2010/Accepted: 12 October 2010/Published online: 7 December 2010 (C) Springer Basel AG 2010

\begin{abstract}
The plasmin-antiplasmin system plays a key role in blood coagulation and fibrinolysis. Plasmin and $\alpha_{2}$-antiplasmin are primarily responsible for a controlled and regulated dissolution of the fibrin polymers into soluble fragments. However, besides plasmin(ogen) and $\alpha_{2}$-antiplasmin the system contains a series of specific activators and inhibitors. The main physiological activators of plasminogen are tissue-type plasminogen activator, which is mainly involved in the dissolution of the fibrin polymers by plasmin, and urokinase-type plasminogen activator, which is primarily responsible for the generation of plasmin activity in the intercellular space. Both activators are multidomain serine proteases. Besides the main physiological inhibitor $\alpha_{2}$-antiplasmin, the plasmin-antiplasmin system is also regulated by the general protease inhibitor $\alpha_{2}$-macroglobulin, a member of the protease inhibitor I39 family. The activity of the plasminogen activators is primarily regulated by the plasminogen activator inhibitors 1 and 2, members of the serine protease inhibitor superfamily.
\end{abstract}

Keywords Plasmin(ogen $) \cdot \alpha_{2}$-Antiplasmin $\cdot$ Serine protease inhibitors (serpins) · Plasminogen activators ·

The recommended names in the UniProt Knowledgebase (SwissProt and TrEMBL) were used. The protein structures are based on the coordinates deposited in the Protein Data Bank (PDB) and were visualized as well as rendered using the software PyMOL. If not stated otherwise, the standard rainbow colour representation was used.

J. Schaller $(\bowtie) \cdot$ S. S. Gerber

Department of Chemistry and Biochemistry,

University of Bern, Freiestrasse 3, 3012 Bern, Switzerland

e-mail: johann.schaller@ibc.unibe.ch
Plasminogen activator inhibitors $\cdot \alpha_{2}$-Macroglobulin Multidomain serine proteases

$\begin{array}{ll}\text { Abbreviations } \\ \text { A2PI } & \alpha_{2} \text {-Antiplasmin, } \alpha_{2} \text {-Plasmin inhibitor } \\ \text { CHO } & \text { Carbohydrate } \\ \text { EGF-like } & \text { Epidermal growth factor-like } \\ \text { FN1 } & \text { Fibronectin type I } \\ \text { K } & \text { Kringle } \\ \text { LBS } & \text { Lysine binding site } \\ \text { LMW } & \text { Low molecular weight } \\ \alpha_{2} \text { M } & \alpha_{2} \text {-Macroglobulin } \\ \text { NTP } & \text { N-terminal peptide of Pgn } \\ \text { PAI-1, }-2 & \text { Plasminogen activator inhibitor } 1,2 \\ \text { Pgn } & \text { Plasminogen } \\ \text { Plm } & \text { Plasmin } \\ \text { RCL } & \text { Reactive centre loop } \\ \text { Serpin } & \text { Serine protease inhibitor } \\ \text { tPA } & \text { Tissue-type plasminogen activator } \\ \text { uPA } & \text { Urokinase-type plasminogen activator } \\ \text { uPAR } & \text { Urokinase-type plasminogen activator receptor }\end{array}$

\section{Introduction [1]}

The plasmin-antiplasmin system holds a key position in blood coagulation and fibrinolysis. A schematic representation of the fibrinolytic system with its main components is given in Fig. 1 [2]. The plasmin-antiplasmin system controls and regulates the dissolution of the fibrin polymers into soluble fragments (for details see later sections). As with every complex system, blood coagulation and fibrinolysis also have to be tightly controlled and regulated. Plasminogen (Pgn) is activated by its two main physiological activators, tissue-type plasminogen activator (tPA) 


\section{fibrinolytic system}

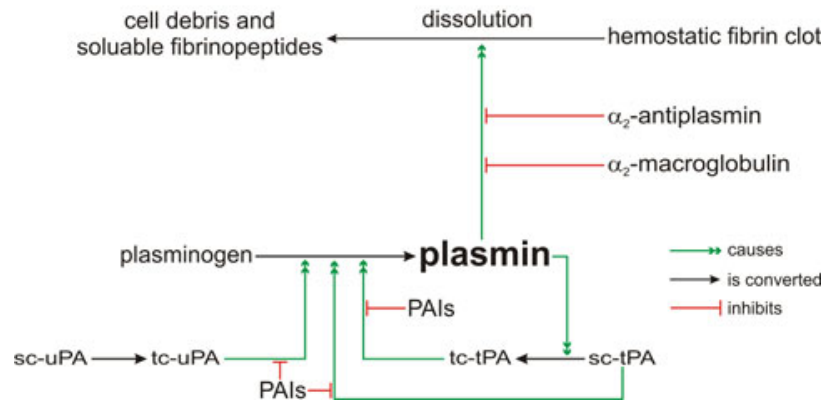

Fig. 1 Schematic representation of the main components of the fibrinolytic system (adapted from reference [2]). $s c-t P A$, $t c-t P A$ single-chain, two-chain tPA; $s c-u P A, t c-u P A$ single-chain, two-chain uPA; PAIs plasminogen activator inhibitors

and urokinase-type plasminogen activator (uPA). Plasmin (Plm) is inhibited by its main physiological inhibitor $\alpha_{2}$-antiplasmin (A2PI) and the general protease inhibitor $\alpha_{2}$-macroglobulin $\left(\alpha_{2} \mathrm{M}\right)$. The activities of tPA and uPA are regulated by their two main physiological inhibitors, the plasminogen activator inhibitors 1 and 2 (PAI-1 and PAI-2).

The structural data for the proteins involved in the plasmin-antiplasmin system discussed in this review article are compiled in Table 1.

\section{Multidomain serine proteases}

Many serine proteases in blood plasma are multidomain proteins, especially those involved in blood coagulation and fibrinolysis and those in the complement system. Usually, serine proteases are present in plasma in their inactive proenzyme or zymogen form. The catalytic activity is normally generated by a specific activation process involving limited proteolysis. The 3-D structure of a serine protease domain is usually characterized by two six-stranded antiparallel $\beta$-barrels surrounded by $\alpha$-helical and 310 -helical segments. The active site cleft with the catalytic triad His, Asp, and Ser is located at the interface of two structurally similar subdomains (see sections: Plasminogen, Tissue-type plasminogen activator, and Urokinase-type plasminogen activator). Besides the serine protease domain, multidomain serine proteases contain specific domains such as kringles, fibronectin (FN), and epidermal growth factor-like (EGF-like) domains, which mediate efficient binding to the target structures thus facilitating an efficient cleavage reaction of the serine protease which is usually strictly limited to the intended site. For instance, efficient binding of plasmin(ogen) to the fibrin blood clot is mediated by the lysine binding sites (LBS) located in the kringle domains of the molecule thus facilitating an efficient cleavage of the fibrin polymer by
Plm into soluble fragments (for details see section Plasminogen). The most important structural data for the multidomain serine proteases Pgn, tPA, and uPA are summarized in Table 1.

\section{Plasminogen [3-6]}

Human Pgn (P00747, EC 3.4.21.7; concentration in plasma 100-200 $\mathrm{mg} \mathrm{l}^{-1}$ ) is a single-chain, multidomain glycoprotein (about 2\% CHO) of about $90 \mathrm{kDa}$ (791 amino acids) and is a member of the peptidase S1 family present in blood as zymogen. Pgn is synthesized mainly in the liver as a protein 810 residues long [7], and mature Pgn, GluPgn, comprises 791 amino acids generated during the secretion process by cleaving the 19-residue signal peptide [8]. Glu-Pgn is the proenzyme form of the serine protease Plm, the key component of the fibrinolytic system (Fig. 1). The gene for Pgn $(P L G, 52.5 \mathrm{~kb})$ is located on chromosome 6q26-6q27 and is organized into 19 exons in the range 75-387 bp [8-10]. In plasma, Pgn is partially bound to histidine-rich glycoprotein (P04196) [11]. Histidine-rich glycoprotein binds at sites of tissue injury and seems to act as a high-affinity receptor to immobilize Pgn on cell surfaces [12].

Pgn is composed of an N-terminal peptide (NTP) [13], five triple-loop structures stabilized by three intrachain disulfide bridges called kringles [14], and the trypsin-like serine protease part carrying the catalytic triad $\mathrm{His}^{603}$, $\mathrm{Asp}^{646}$, and $\mathrm{Ser}^{741}$ [15]. Human Pgn is partially N-glycosylated at $\mathrm{Asn}^{289}$ and O-glycosylated at $\mathrm{Ser}^{249}$ and $\mathrm{Thr}^{346}$ giving rise to Pgn variants I $\left(\mathrm{Asn}^{289}, \mathrm{Thr}^{346}\right)$ and II (only $\mathrm{Thr}^{346}$ ), which can be readily separated by affinity chromatography [16-20]. In addition, Pgn is partially phosphorylated at $\operatorname{Ser}^{578}$ [21] with a so far unassigned function. The schematic organization of the primary structure of human Pgn is shown in Fig. 2 [2]. Two N-terminally different forms of Pgn have been identified, Glu-Pgn and Lys-Pgn. Lys-Pgn is formed by cleavage of the Lys $^{77}-$ Lys $^{78}$ peptide bond in Glu-Pgn, releasing the NTP [22].

Pgn is activated by the two main physiological plasminogen activators, tPA and uPA [23], to the active, twochain Plm molecule held together by two interchain disulfide bridges $\left(\mathrm{Cys}^{548}{ }^{5} \mathrm{Cys}^{666}, \mathrm{Cys}^{558}-\mathrm{Cys}^{566}\right.$ ) by cleavage of the $\mathrm{Arg}^{561}-\mathrm{Val}^{562}$ peptide bond and the release of the 77-residue NTP [24, 25]. Upon activation, Pgn undergoes an unusual conformational change usually not observed in proenzyme-enzyme pairs of the trypsin-type family [25]. Native Glu-Pgn exhibits a compact spiral shape, whereas Lys-Pgn and Plm have a more open, elongated structure. In addition to tPA and uPA, two bacteria-derived proteins, streptokinase A or C (A: P10520; 
Table 1 Structural data for the main proteins involved in the plasmin-antiplasmin system

\begin{tabular}{|c|c|c|c|c|c|c|c|}
\hline \multirow[t]{2}{*}{ Protein (abbreviation) } & \multirow[t]{2}{*}{ UniProt entry } & \multicolumn{2}{|l|}{$\mathrm{Size}^{\mathrm{b}}$} & \multirow{2}{*}{$\begin{array}{l}\text { Plasma } \\
\text { concentration } \\
\left(\mathrm{mg} \mathrm{l}^{-1}\right)\end{array}$} & \multicolumn{2}{|l|}{ Gene } & \multirow[t]{2}{*}{ Domains } \\
\hline & & Daltons & $\begin{array}{l}\text { Amino } \\
\text { acids }\end{array}$ & & Name & $\begin{array}{l}\text { Size } \\
(\mathrm{kb})\end{array}$ & \\
\hline Plasminogen (Pgn) & P00747/EC 3.4.21.7 & 88,432 & 791 & $100-200$ & $P L G$ & 52.5 & $\begin{array}{l}1 \text { NTP of Pgn, } 5 \mathrm{~K} \text {, } \\
\text { serine protease }\end{array}$ \\
\hline $\begin{array}{l}\text { Tissue-type plasminogen } \\
\text { activator (tPA) }\end{array}$ & P00750/EC 3.4.21.68 & 59,042 & 527 & $0.005-0.01$ & $P L A T$ & 32.4 & $\begin{array}{l}1 \text { EGF-like, } 2 \mathrm{~K} \text {, } \\
1 \mathrm{FN} 1, \\
\text { serine protease }\end{array}$ \\
\hline $\begin{array}{l}\text { Urokinase-type plasminogen } \\
\text { activator (uPA) }\end{array}$ & P00749/EC 3.4.21.73 & 46,386 & 411 & $0.005-0.01$ & $P L A U$ & 6.4 & $\begin{array}{l}1 \text { EGF-like, } \\
1 \mathrm{~K} \text {, serine } \\
\text { protease }\end{array}$ \\
\hline$\alpha_{2}$-Antiplasmin (A2PI) & P08697 & 50,451 & 452 & $\sim 70$ & SERPINF2 & $\sim 16$ & \\
\hline$\alpha_{2}$-Macroglobulin $\left(\alpha_{2} \mathrm{M}\right)$ & P01023 & 160,797 & 1,451 & $\sim 1,200$ & $A 2 M$ & $\sim 48$ & \\
\hline $\begin{array}{l}\text { Plasminogen activator } \\
\text { inhibitor } 1 \text { (PAI-1) }\end{array}$ & P05121 & 42,769 & 379 & $\sim 0.024$ (variable) & SERPINE1 & 12.2 & \\
\hline $\begin{array}{l}\text { Plasminogen activator } \\
\text { inhibitor } 2 \text { (PAI-2) }\end{array}$ & P05120 & 46,596 & 415 & $<0.01$ & SERPINB2 & 16.4 & \\
\hline Neuroserpin & Q99574 & 44,704 & 394 & not detectable & SERPINII & 89.8 & \\
\hline Glia-derived nexin & P07093 & 41,865 & 379 & & SERPINE2 & - & \\
\hline
\end{tabular}

b Mass calculated from the amino acid sequence

Fig. 2 Schematic representation of the primary structure of human Pgn (from reference [2]). The catalytic triad $\left(\mathrm{His}^{603}, \mathrm{Asp}^{646}\right.$, and $\mathrm{Ser}^{741}$ ), the activation site $\left(\mathrm{Arg}^{561}-\mathrm{Val}^{562}\right)$, the Plm cleavage site $\left(\mathrm{Lys}^{77}-\mathrm{Lys}^{78}\right)$, the phosphorylation site $\left(\mathrm{Ser}^{578}\right)$, the $\mathrm{CHO}$ attachment sites $\left(\mathrm{Asn}^{289}, \mathrm{Ser}^{249}\right.$, and $\left.\mathrm{Thr}^{346}\right)$, and the 24 disulfide bridges as well as the signal peptide are indicated. NTP N-terminal peptide; $K 1-K 5$ kringles $1-5$

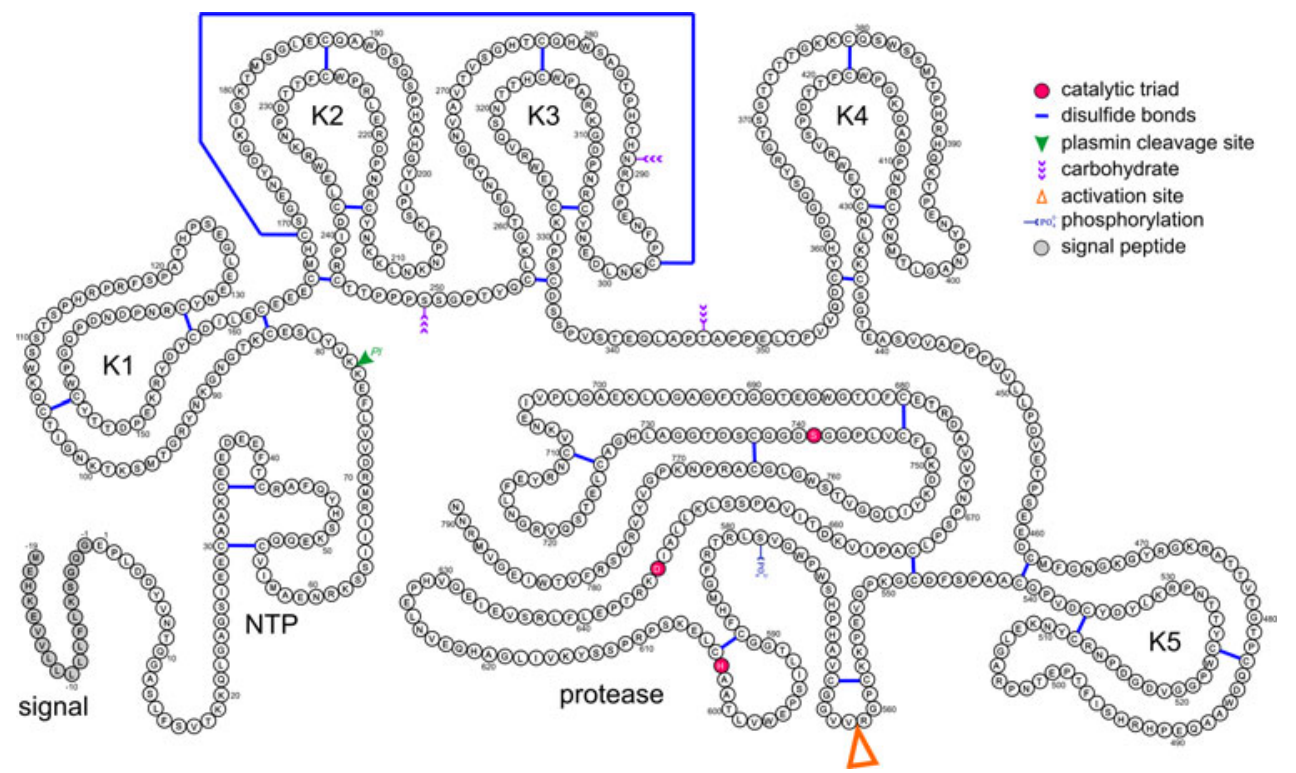

C: P00779) and staphylokinase (P68802), can act as Pgn activators. They form equimolar complexes with Pgn, and this complex is able to activate Pgn [26, 27].

The heavy chain of Plm (483 amino acids) contains five homologous kringle structures, $\mathrm{K} 1 \quad\left(\mathrm{Cys}^{84}-\mathrm{Cys}^{162}\right)$, K2 $\left(\mathrm{Cys}^{166}-\mathrm{Cys}^{243}\right), \mathrm{K} 3\left(\mathrm{Cys}^{256}-\mathrm{Cys}^{333}\right), \mathrm{K} 4\left(\mathrm{Cys}^{358}-\mathrm{Cys}^{435}\right)$, and $\mathrm{K} 5\left(\mathrm{Cys}^{462}-\mathrm{Cys}^{541}\right)$, with the disulfide bridges arranged in the pattern $\mathrm{Cys}^{1}-\mathrm{Cys}^{6}{ }^{6} \mathrm{Cys}^{2}-\mathrm{Cys}^{4}, \mathrm{Cys}^{3}-\mathrm{Cys}^{5}$. Kringles 2 and 3 are linked together in a clamp-like fashion by an additional interkringle disulfide bridge $\left(\right.$ Cys $\left.^{169}-\mathrm{Cys}^{297}\right)$. With the exception of K3, each kringle contains a functional LBS characterized by anionic and cationic centres interspaced by a hydrophobic groove. In the case of human Pgn K1, the anionic and cationic centres contain two Asp and two Arg residues, respectively, and the hydrophobic groove is lined out with aromatic residues (one Trp, three Tyr, and one Phe) [28, 29]. The LBS mediate binding to the substrate fibrin(ogen) [30] and to its main physiological inhibitor A2PI [31-33] and to small molecules of the $\omega$-aminocarboxylic acid type such as 
Fig. 3 Top and bottom 3-D structural model of human Pgn based on overlapping 3-D structures of Pgn fragments (form reference [44]). Each kringle is shown in grey, the central Trp residue in each LBS is shown in magenta, the protease domain is shown in green, and the active site residues are shown in red

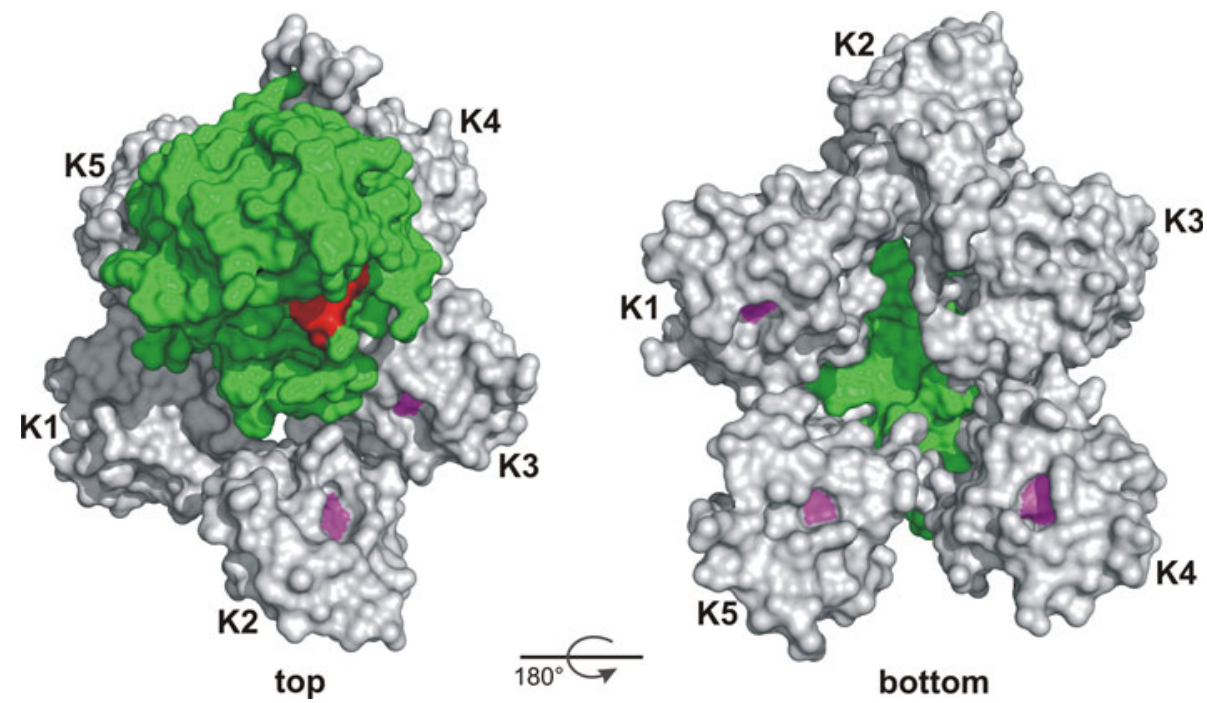

6-aminohexanoic acid [34]. In addition, specific binding via kringle domain(s) to bacteria $[35,36]$ and to mammalian cell surfaces [37] has been described. K3 is the only kringle with a functionally inactive LBS [38, 39], but substitution of Lys ${ }^{311}$ to Asp in the anionic centre of the LBS results in a weak but distinct affinity for $\omega$-aminocarboxylic acids [40]. The affinity of the antifibrinolytic drug 6-aminohexanoic acid for the various kringles decreases in the order $\mathrm{K} 1>\mathrm{K} 4>\mathrm{K} 5>\mathrm{K} 2>>\mathrm{K} 3$ [41-43].

So far, no 3-D structure of complete human Pgn is available. A 3-D structural model of human Pgn based on known and overlapping 3-D structures of Pgn fragments exhibits the spiral shape shown in Fig. 3 [44], which resembles the known shape of Glu-Pgn visualized by electron microscopy [45, 46]. However, 3-D structural data for all kringle domains and of the catalytic chain are available. As an example, the 3-D structures of the triplekringle domain $\mathrm{K} 1+2+3$ termed angiostatin (1KI0), determined by X-ray diffraction, is shown in Fig. 4 [47]. The kringle structures are characterized by a central cluster of four Cys residues composed of the two inner disulfide bridges $\left(\mathrm{Cys}^{2}-\mathrm{Cys}^{4}, \mathrm{Cys}^{3}-\mathrm{Cys}^{5}\right)$, which are almost perpendicular to each other (as an example, see K2). The kringle domains have a rather low content of secondary structure with some $\beta$-strands but usually a low helical content. As an example, $\mathrm{K} 1$ is given in the surface representation with negatively and positively charged residues shown in red and in blue, respectively, and all other residues are shown in grey. The central Trp residue of the LBS is marked in magenta (indicated by an arrow). The binding of a ligand has little influence on the conformation but stabilizes the structure. The 3-D structure of the catalytic domain of human Pgn determined by X-ray diffraction (1DDJ) exhibits the expected trypsin-like shape, and is

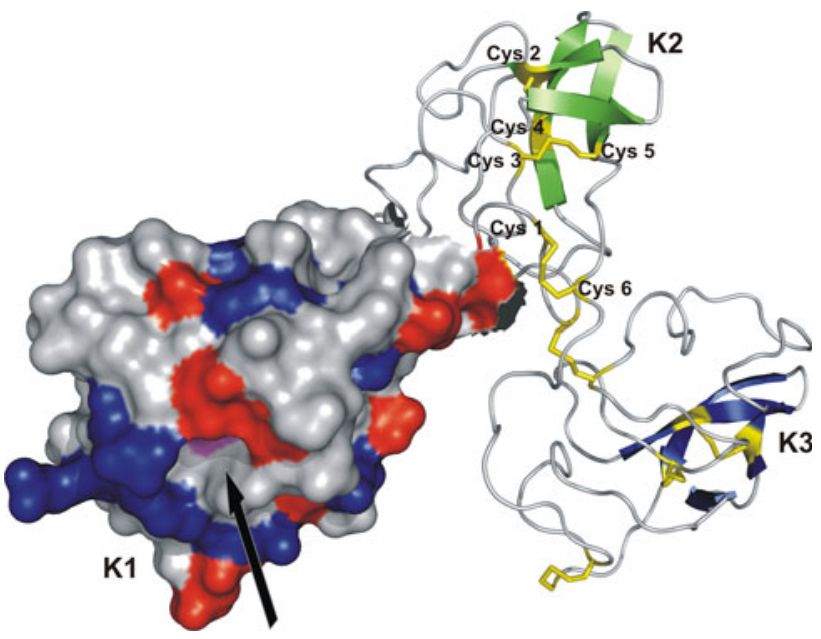

Fig. 4 3-D structure of human Pgn kringles $1+2+3(K 1, K 2, K 3)$ termed angiostatin determined by X-ray diffraction (1KI0, [47]). Each kringle contains three disulfide bridges (yellow) arranged in the pattern $\mathrm{Cys}^{1}-\mathrm{Cys}^{6}, \mathrm{Cys}^{2}-\mathrm{Cys}^{4}, \mathrm{Cys}^{3}-\mathrm{Cys}^{5}$ exemplified in kringle 2 $(K 2)$. Kringle $1(K 1)$ is shown as a surface representation with negatively and positively charged residues shown in red and blue, respectively, and all other residues are shown in grey. The central Trp residue of the LBS is shown in magenta (arrow)

shown in Fig. 5 [25]. Each of the two structurally similar subdomains is characterized by an antiparallel $\beta$-barrel and the active site cleft is located at the interface of the two subdomains.

The primary function of Plm is the cleavage of insoluble fibrin polymers at specific sites resulting in soluble fragments. A schematic representation of fibrinogen and the pattern of cleavage by Plm is shown in Fig. 6 [48]. The cleavage sites giving rise to the major fragments $\mathrm{D}$ and $\mathrm{E}$ of fibrin are indicated by black arrows. The degradation of the fibrin polymer by Plm is initiated by the cleavage of the Lys $^{583}-\mathrm{Met}^{584}$ peptide bond in the A $\alpha$ chain, followed by 


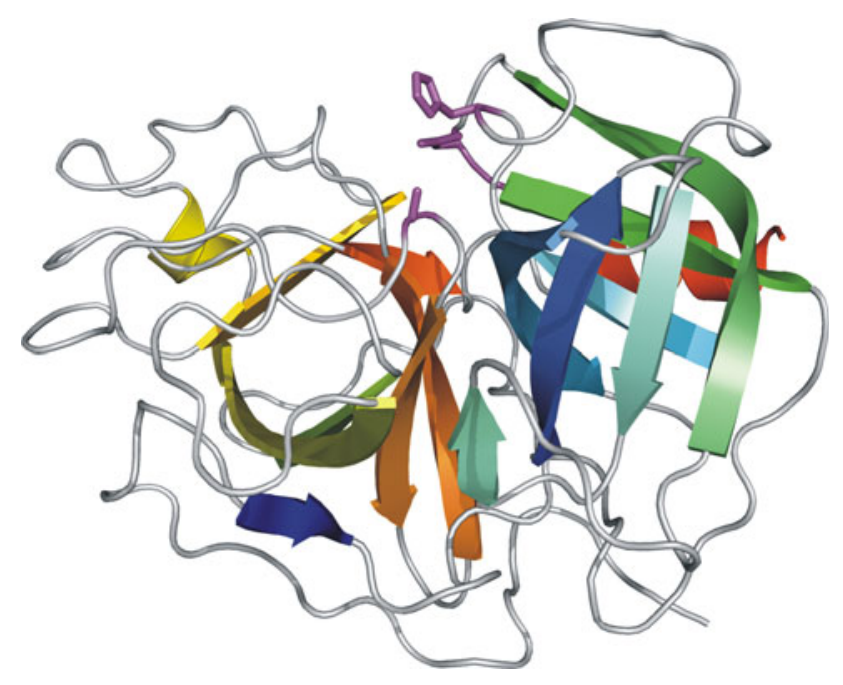

Fig. 5 3-D structure of the catalytic domain of human Pgn determined by X-ray diffraction (1DDJ, [25]). The active site residues located at the interface of the two structurally similar subdomains are shown in magenta

the cleavage of the peptide bonds $\mathrm{Lys}^{206}-\mathrm{Met}^{207}$ and $\mathrm{Lys}^{230}-\mathrm{Ala}^{231}$, also in the $\mathrm{A} \alpha$ chain, thus releasing a C-terminal $40-\mathrm{kDa}$ fragment and generating fragment $\mathrm{X}$ $(260 \mathrm{kDa})$. Cleavage of fragment $X$ in all three chains results in one fragment $\mathrm{Y}(160 \mathrm{kDa})$ and one fragment $\mathrm{D}$ $(100 \mathrm{kDa})$, and further cleavage of fragment $\mathrm{Y}$ produces a second fragment $\mathrm{D}$ and fragment $\mathrm{E}(60 \mathrm{kDa})$ [48].

In addition, Plm acts as a proteolytic factor in many other physiological processes such as mediation of cell migration by degrading the extracellular matrix, wound healing, tissue remodelling, angiogenesis, embryogenesis, and pathogen and tumour cell invasion [23, 49-54]. The rather broad specificity of Plm in vivo results in the inactivation and degradation of matrix proteins such as collagens, fibronectin (P02751), and laminins [55-57], and components of the blood coagulation cascade such as coagulation factor FVa, von Willebrand factor, and thrombospondin $[56,58,59]$. In vitro, Plm has a similar specificity to trypsin cleaving primarily peptide bonds after basic residues. The main physiological inhibitor of Plm is A2PI, a serpin, which is discussed in section $\alpha_{2}$-Antiplasmin or $\alpha_{2}$-plasmin inhibitor.

Defects or mutations in the PLG gene are the cause of thrombophilia (MIM 188050) [60], a form of recurrent thrombosis, and type I plasminogen deficiency (MIM 173350). Ligneous conjunctivitis (MIM 217090) is usually the most common and initial form of type I plasminogen deficiency and is a rare form of chronic conjunctivitis characterized by chronic tearing and redness of the conjunctivae [61, 62].

\section{Plasminogen activators}

There are two main physiological activators of Pgn, tPA and UPA, which are both multidomain serine proteases previously mentioned (see Table 1). Although tPA and uPA both catalyse the same reaction, namely the activation of Pgn to Plm by cleavage of the $\mathrm{Arg}^{561}-\mathrm{Val}^{562}$ peptide bond, and thus clearly have the same basic biological function at the molecular level, tPA and uPA have different biological roles. Whereas tPA is primarily responsible for the dissolution of the fibrin polymers by Plm and thus helps to maintain vascular haemostasis, uPA is predominantly involved in the generation of pericellular Plm activity for the degradation of the extracellular matrix and for other intercellular processes where Plm activity is required.
Fig. 6 Cleavage of human fibrinogen by Plm (from reference [48]). Schematic representation of fibrinogen, the fibrin polymer, the pattern of cleavage by Plm, and the main fragments generated. The main Plm cleavage sites are indicated by arrows. Cleavage of fibrin by Plm leads to the main fragments X (260 kDa), Y (160 kDa), D (100 kDa), and E (60 kDa)
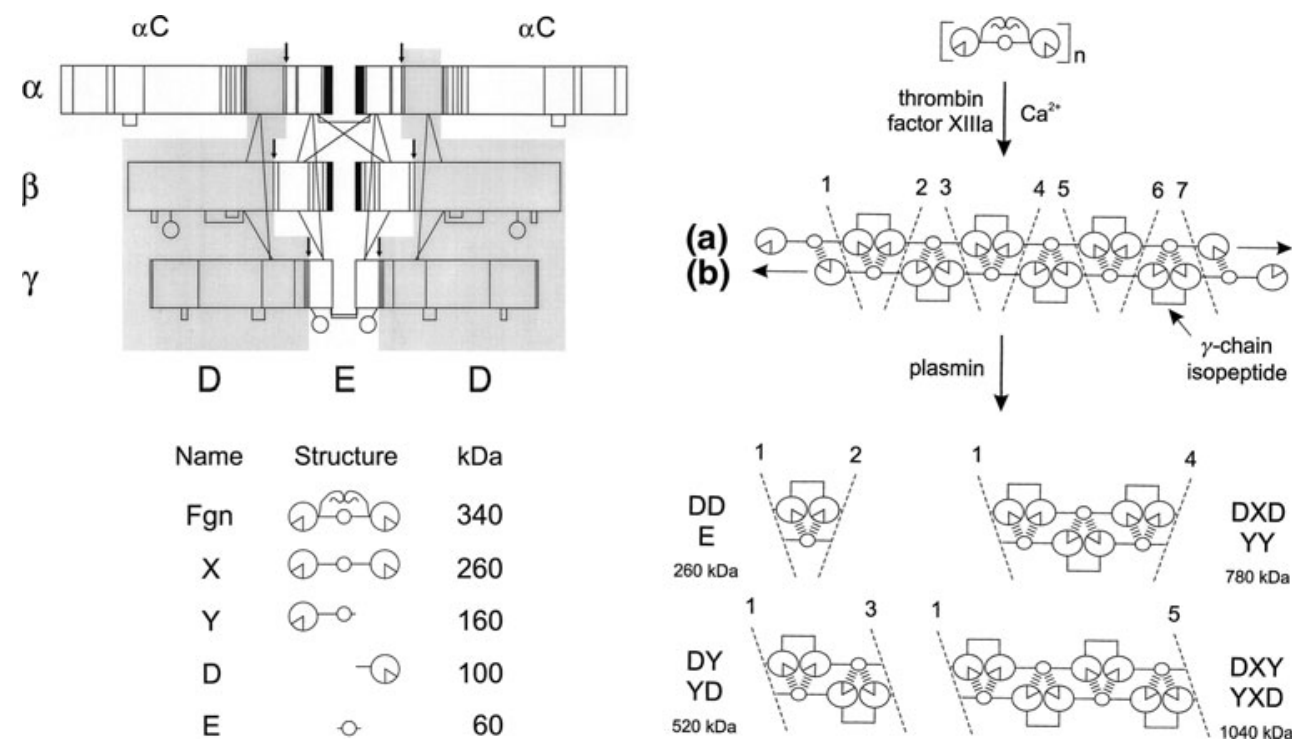
Tissue-type plasminogen activator

Human tPA (P00750, EC 3.4.21.68; concentration in plasma $5-10 \mu \mathrm{g} \mathrm{l}^{-1}$ ) is synthesized by various cell types such as endothelial cells and keratinocytes and also in the brain $[63,64]$. It is a single-chain multidomain glycoprotein (about $7 \% \mathrm{CHO}$ ) of $70 \mathrm{kDa}$ (527 amino acids) containing one O-glycosylation site at $\mathrm{Thr}^{61}$ and three $\mathrm{N}$-glycosylation sites at $\mathrm{Asn}^{117}, \mathrm{Asn}^{184}$ (partial), and $\operatorname{Asn}^{448}[65,66]$ and belongs to the peptidase S1 family [67]. The tPA gene (PLAT, $32.4 \mathrm{~kb})$ is located on chromosome $8 \mathrm{p} 12$ and is organized into 14 exons in the range 43-914 bp [68, 69]. The single-chain form (proenzyme) itself exhibits a very high enzymatic activity compared with the fully active two-chain form of tPA, which is a unique property of the proenzyme form of serine proteases. The single-chain form is converted to the completely active, two-chain form held together by a single interchain disulfide bridge $\left(\mathrm{Cys}^{264}-\mathrm{Cys}^{395}\right)$ upon cleavage of the $\mathrm{Arg}^{275} \mathrm{Ile}^{276}$ peptide bond by Plm, kallikrein, or coagulation factor $\mathrm{Xa}$ [70]. The A-chain (275 amino acids) contains one FN1, one EGF-like, and two kringle domains and the B-chain (252 amino acids) comprises the serine protease part [71]. The second kringle in tPA carries an active LBS as do the kringles in Pgn [72], but kringle 1 is devoid of an active LBS. This seems to be due to the replacement of the usual Trp residue by a Ser in the hydrophobic cleft of the LBS in tPA kringle 1 [73].

The 3-D structure of the double module FN1+EGF-like was determined by NMR spectroscopy (1TPG) and is shown in Fig. 7a [74]. The FN1 domain (43 amino acids) is characterized by two antiparallel $\beta$-sheets, a double stranded sheet and a triple-stranded sheet (shown in red), stabilized by two intrachain disulfide bridges arranged in the pattern $\mathrm{Cys}^{1}-\mathrm{Cys}^{3}, \mathrm{Cys}^{2}-\mathrm{Cys}^{4}$. The first disulfide bridge links the two $\beta$-sheets, the second disulfide bridge is located within the triple-stranded $\beta$-sheet. The EGF-like domain (39 amino acids) is characterized by two antiparallel, two-stranded $\beta$-sheets (shown in blue) interconnected by a loop structure. The structure is stabilized by three intrachain disulfide bridges arranged in the pattern $\mathrm{Cys}^{1}-\mathrm{Cys}^{3}, \mathrm{Cys}^{2}-\mathrm{Cys}^{4}, \mathrm{Cys}^{5}-\mathrm{Cys}^{6}$. It appears that the FN1+EGF-like double module, the two kringles, and the serine protease domain are involved in the interaction of tPA with fibrin $[75,76]$. tPA binds with high affinity to fibrin, resulting in an enhanced activation of Pgn by tPA. Exposed C-terminal Lys and Arg residues in fibrin generated by proteolysis with Plm bind to the LBS in kringle 2 of tPA [77]. The 3-D structure of the catalytic domain of human tPA in complex with a low molecular weight (LMW) inhibitor (dansyl-EGR-chloromethyl ketone) was determined by X-ray diffraction (1RTF) and exhibits the expected trypsin-like fold (Fig. 7b) [78]. The inhibitor is
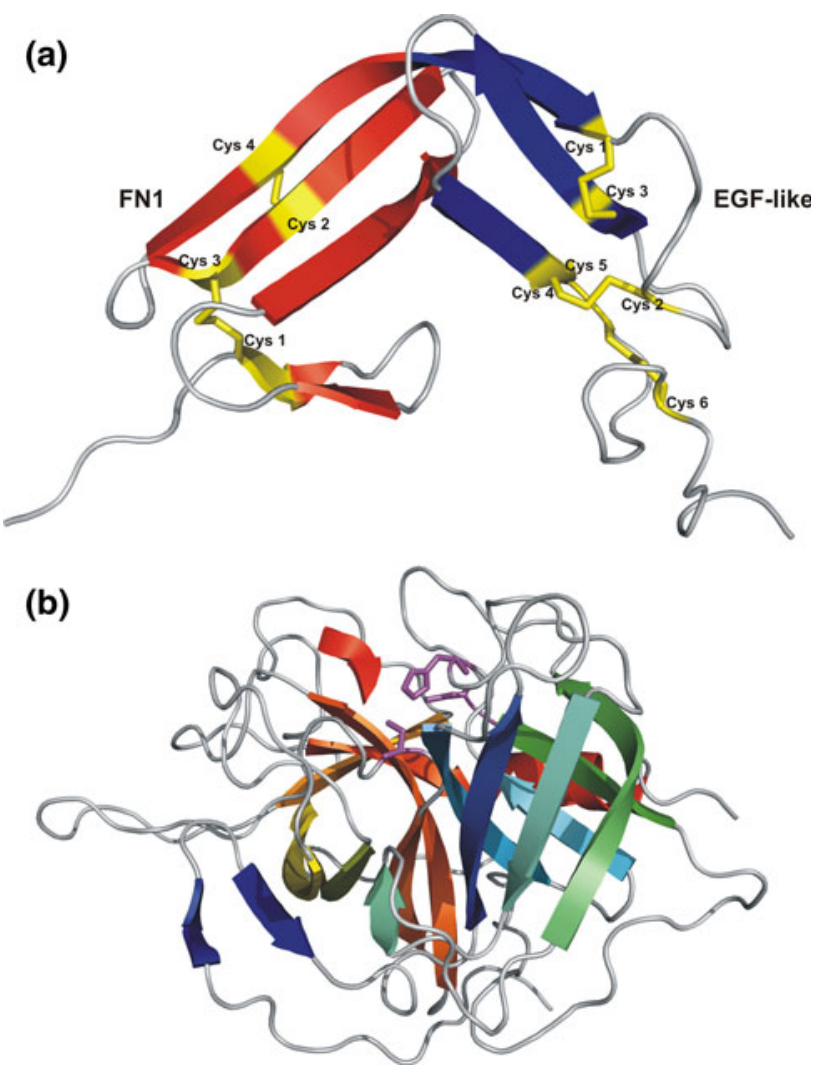

Fig. 7 a 3-D structure of the double module of human tPA comprising the fibronectin type I ( FN1) domain and the epidermal growth factor-like (EGF-like) domain determined by NMR spectroscopy (1TPG, [74]). The disulfide bridges shown in yellow exhibit the following patterns: in FN1 (red) $\mathrm{Cys}^{1}-\mathrm{Cys}^{3}$, $\mathrm{Cys}^{2}-\mathrm{Cys}^{4}$, and in EGFlike (blue) $\mathrm{Cys}^{1}-\mathrm{Cys}^{3}, \mathrm{Cys}^{2}-\mathrm{Cys}^{4}, \mathrm{Cys}^{5}-\mathrm{Cys}{ }^{6}$. b 3-D structure of the catalytic domain of human tPA in complex with the LMW inhibitor dansyl-EGR-chloromethyl ketone determined by X-ray diffraction (1BDA, [78]). The inhibitor shown in red is covalently bound to $\mathrm{His}^{322}$ and $\mathrm{Ser}^{478}$ in the active site cleft (magenta)

covalently bound to $\mathrm{His}^{322}$ and $\mathrm{Ser}^{478}$ in the active site cleft of tPA located at the interface of the two subdomains. Lys ${ }^{429}$ forms a salt bridge with $\mathrm{Asp}^{477}$ promoting an active conformation in single-chain tPA. The single-chain, proenzyme form of tPA exhibits only a five to tenfold decreased activity compared with fully active, two-chain tPA [79]. Both forms seem to exhibit the same biological function.

Interactions of tPA with endothelial cells and smooth muscle vascular cells lead to an increased activation of Pgn. In the case of endothelial cells, the $\mathrm{Ca}^{2+}$ /phospholipid-binding protein annexin A2 (P07755) binds via its exposed C-terminal Lys and Arg residues to the kringle 2 domain of tPA [80, 81].

The main physiological inhibitors of tPA are PAI-1 and PAI-2, which are discussed in section Plasminogen activator inhibitor 1 and Plasminogen activator inhibitor 2, respectively. An increased activity of tPA leads to hyperfibrinolysis (MIM 173370), an excessive bleeding disorder 
[82]. There are several forms of tPA in therapeutic use, among them alteplase (Activase, Genentech) and reteplase (Retavase, Centocor, and Roche), which are used to initiate fibrinolysis in the case of acute myocardial infarction, acute ischaemic stroke, and pulmonary embolism.

Urokinase-type plasminogen activator

Human uPA (P00749, EC 3.4.21.73; concentration in plasma $5-10 \mu \mathrm{g}^{-1}$ ) is synthesized in the lung and the kidney, but also in keratinocytes and endothelial cells [83, 84]. It is a single-chain multidomain glycoprotein (about $2 \% \mathrm{CHO}$ ) of $55 \mathrm{kDa}$ (411 amino acids) [85, 86] containing one O-glycosylation site at $\mathrm{Thr}^{18}$ and one $\mathrm{N}$-glycosylation site at $\mathrm{Asn}^{302}$ and two phosphorylation sites at $\mathrm{Ser}^{138}$ and $\mathrm{Ser}^{303}[87,88]$. The phosphorylation of $\mathrm{Ser}^{138} / \mathrm{Ser}^{303}$ seems to modulate the urokinase receptor (uPAR) transducing ability [88]. The uPA gene (PLAU, 6.4 kb) is located on chromosome 10q24 and is organized into 11 exons [89]. Human uPA is converted to its active, two-chain high molecular weight form held together by a single interchain disulfide bridge $\left(\mathrm{Cys}^{148}-\mathrm{Cys}^{279}\right.$ ) upon cleavage of the Lys ${ }^{158}-\mathrm{Ile}^{159}$ peptide bond by Plm, kallikrein, coagulation factor XIIa, or cathepsin [90]. The A-chain (157 amino acids) contains one EGF-like and one kringle domain and the B-chain (253 amino acids) comprises the serine protease part. In addition to the high molecular weight form, there is also a LMW form of UPA, the major form found in urine. The LMW form of uPA is generated by Plm or by uPA itself cleaving the Lys ${ }^{135}$-Lys ${ }^{136}$ peptide bond. Thus LMW uPA is devoid of the EGF-like and kringle domains, and the former A-chain consists only of a minichain (22 amino acids) linked to the catalytic domain by a single interchain disulfide bridge [91].

The 3-D structure of the double domain EGFlike+kringle determined by NMR spectroscopy (1URK) is shown in Fig. 8a [92]. The EGF-like module exhibits the same structural fold as the corresponding domain in tPA (Fig. 7a) and the kringle domain resembles the kringles in other kringle-containing proteins, e.g. human Pgn (Fig. 4). The kringle structure in uPA is devoid of an active LBS due to the replacement of essential residues in the cationic (Lys $\rightarrow$ Tyr) and anionic (Asp $\rightarrow$ Arg) centres and two aromatic residues in the hydrophobic groove of the LBS. Three consecutive Arg residues $\left(\operatorname{Arg}^{108}-\mathrm{Arg}^{110}\right)$ and two His residues (His ${ }^{85}$ and $\mathrm{His}^{87}$ ) at the opposite ends of the kringle domain are involved in heparin binding [93, 94]. The EGF-like module mediates binding to its specific cellular receptor uPAR [95, 96]. The 3-D structure of human LMW uPA was determined by X-ray diffraction (1GJA) and is shown in Fig. 8b [97]. The serine protease part exhibits the expected trypsin-like fold with two subdomains each containing one antiparallel $\beta$-barrel and the

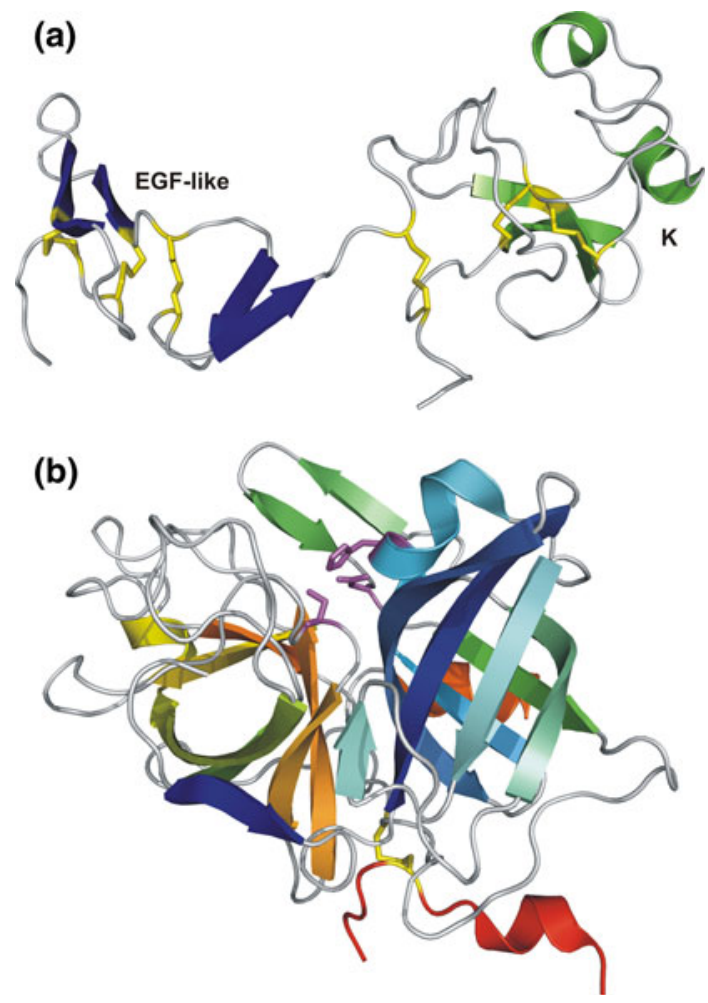

Fig. 8 a 3-D structure of the EGF-like (blue) and kringle (green) double domain of human uPA determined by NMR spectroscopy (1URK, [92]). The disulfide bridges are shown in yellow and are arranged as in Fig. 7a (EGF-like) and Fig. 4 (kringle). b 3-D structure of human LMW uPA determined by X-ray diffraction (1GJA, [96]). The minichain (red) is linked to the catalytic domain by a single interchain disulfide bridge (yellow)

active site cleft with the catalytic triad is located at the interface of the two subdomains. The minichain (in red) is linked to the catalytic domain by a single interchain disulfide bridge (in yellow).

The main physiological inhibitors of uPA are PAI-1 and PAI-2, which are discussed in section Plasminogen activator inhibitor 1 and Plasminogen activator inhibitor 2, respectively. The uPA system consisting of the serine proteases Plm and uPA, the serpins A2PI, PAI-1, and PAI-2, and uPAR seems to play an important role in cancer metastasis [98]. uPA is available under the name Abbokinase (Abbott) and is used clinically in the treatment of thrombolytic disorders (pulmonary embolism).

\section{Serine protease inhibitors (serpins) [99-102]}

The regulation of proteolytic activity is a fundamental process in all living organisms. Serine protease inhibitors (serpins) are inhibitors (mass range $40-70 \mathrm{kDa}$ ) of serine proteases and more than 1,500 serpin-like genes have been identified so far in all three kingdoms of life as well as in 
viruses [101, 103, 104]. Serpins regulate very diverse physiological processes such as coagulation and fibrinolysis, complement activation, inflammation, angiogenesis, apoptosis, neoplasia, and viral pathogenesis.

Inhibitory serpins are different from other inhibitors in blood plasma in the sense that they are consumed in a oneto-one reaction known as 'suicide inhibition'. The standard serpin structure is characterized by a conserved core structure usually built of three $\beta$-sheets (A, B, and C in red, green, and yellow, respectively), nine $\alpha$-helices (hA-hI in grey), and the reactive centre loop (RCL in blue) containing the serine protease recognition site with the scissile peptide bond $\left(\mathrm{P} 1-\mathrm{P} 1^{\prime}\right)$. Serpins exist in different conformational states, some of which have been characterized in detail as can be seen in Fig. 9 [100]. The various conformational states carry characteristic features:

1. The native state: the native state is usually characterized by three $\beta$-sheets $\mathrm{A}, \mathrm{B}$, and $\mathrm{C}$, nine $\alpha$-helices $\mathrm{hA}-\mathrm{hI}$, and an RCL of approximately 20 amino acids located on the surface of the molecule.

2. The latent, inserted state: in the latent state the RCL is inserted into $\beta$-sheet $\mathrm{A}$. This uncleaved, stressed state is metastable and is often compared with a spring under tension.

3. The cleaved state: in the cleaved state the stress is released, the scissile peptide bond $\mathrm{P} 1-\mathrm{P}^{\prime}$ in the RCL is cleaved, and the $\mathrm{N}$ - and $\mathrm{C}$-terminal ends of the cleaved peptide bond are now on either side of the molecule, often as far apart as $70 \AA$.

4. The serpin-serine protease complex: in the first step of the inhibition reaction a noncovalent Michaelis-like complex is formed between the serpin and the serine protease characterized by an interaction between the RCL of the serpin and the catalytic triad of the serine protease.

5. Cleaved serpin with inactivated serine protease: upon insertion of the RCL into $\beta$-sheet $\mathrm{A}$ the serine protease is drawn from one side of the serpin to the opposite side and the cleavage of the reactive peptide bond releases the tension. The serpin is now covalently linked to the side-chain of the serine residue in the catalytic triad of the serine protease.

The inhibition of a serine protease by a serpin is a twostage process [105]:

1. The first step is a fast and reversible second-order reaction leading to a noncovalent 1:1 Michaelis-like complex of the serpin with the serine protease.

2. The second step is a slower and irreversible firstorder reaction with the insertion of the RCL into $\beta$-sheet $\mathrm{A}$ and the subsequent cleavage of the reactive peptide bond $\mathrm{P} 1-\mathrm{P} 1^{\prime}$ in the $\mathrm{RCL}$, resulting in the covalent attachment of the serpin to the sidechain of the Ser residue in the catalytic triad of the serine protease.

\section{Plasmin inhibitors}

The main physiological inhibitor of Plm is the serpin A2PI which has unique $\mathrm{N}$ - and $\mathrm{C}$-terminal extensions and as a (a)

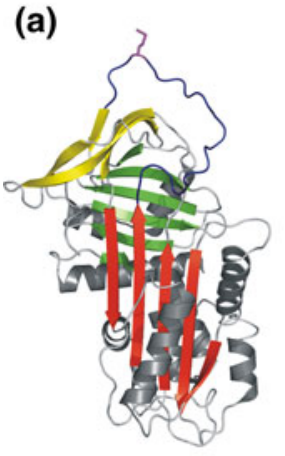

(b)

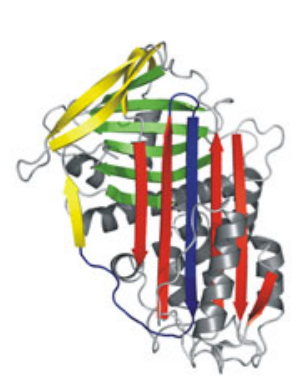

(c)

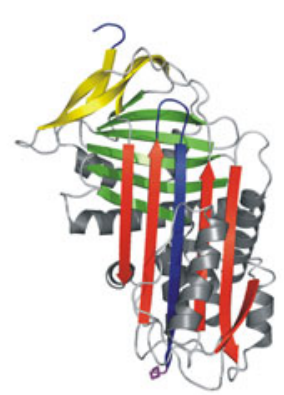

(d)

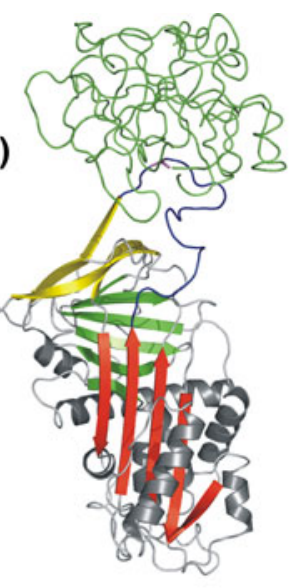

(e)

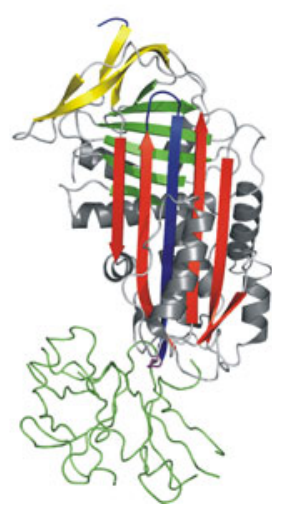

Fig. 9 Various conformational states of serpins [100]. a Native state of human $\alpha_{1}$-antitrypsin (1QLP). b Latent, inserted state of human antithrombin III (2ANT). c Cleaved state of human $\alpha_{1}$-antitrypsin (7API). d Noncovalent, Michaelis-like complex of alaserpin (from
Manduca sexta) in complex with rat trypsin (1199). e Cleaved serpin with inactivated serine protease of human $\alpha_{1}$-antitrypsin with bovine trypsin (1EZX) 
consequence also has special biological properties. In addition, Plm activity is also regulated by the general protease inhibitor $\alpha_{2} \mathrm{M}$.

$\alpha_{2}$-Antiplasmin or $\alpha_{2}$-plasmin inhibitor [106, 107]

Human A2PI, also termed $\alpha_{2}$-plasmin inhibitor (P08697; concentration in plasma: about $70 \mathrm{mg}^{-1}$ ), a member of the serpin superfamily, is a single-chain plasma glycoprotein $(14 \% \mathrm{CHO})$ of about $67 \mathrm{kDa}$ primarily synthesized in the liver [108, 109]. It contains four fully glycosylated N-glycosylation sites $\left(\mathrm{Asn}^{87}, \mathrm{Asn}^{250}, \mathrm{Asn}^{270}, \mathrm{Asn}^{277}\right)[110$, 111], a single disulfide bridge $\left(\mathrm{Cys}^{31}-\mathrm{Cys}^{104}\right)$, two Cys residues ( $\mathrm{Cys}^{64}$ and $\mathrm{Cys}^{113}$ ) of undefined state [112], and a sulfated Tyr residue $\left(\mathrm{Tyr}^{445}\right)$ of unknown function [113]. The A2PI gene (SERPINF2, about $16 \mathrm{~kb}$ ) is located on chromosome $17 \mathrm{p} 13.3$ and is organized into ten exons [114]. In human plasma, two N-terminally different forms are in circulation: (1) a form with 464 residues with Met as $\mathrm{N}$-terminus (Met-A2PI), and (2) a form with 452 residues with Asn as N-terminus (Asn-A2PI) [115, 116]. Approximately $30 \%$ of mature A2PI circulates in human plasma in a C-terminally truncated form lacking at least 26 amino acids [117]. This truncated form inhibits Plm less rapidly than mature A2PI [118, 119]. The RCL contains the scissile peptide bond $\mathrm{P} 1-\mathrm{P} 1^{\prime}$ at $\mathrm{Arg}^{364}-\mathrm{Met}^{365}$ [120]. So far, no 3-D structure of human A2PI is available. However, the 3-D structure of a N-terminally truncated form of murine A2PI (Q61247) sharing 71\% sequence identity with human A2PI was determined by X-ray diffraction (2R9Y) [121]. As expected, murine A2PI exhibits the typical fold of the serpin core structure with three $\beta$-sheets and nine $\alpha$-helices. However, the 3-D structures of the unique $\mathrm{N}$ - and $\mathrm{C}$-terminal extensions of A2PI are still unsolved. In the N-terminal segment of A2PI Gln ${ }^{2}$ forms an isopeptide bond with $\mathrm{Lys}^{303}$ in the $\mathrm{A} \alpha$ chain of fibrin(ogen) catalysed by activated coagulation factor XIIIa [122, 123]. The unique C-terminal extension of A2PI (about 55 amino acids) containing the plasmin(ogen) binding site reveals a remarkable sequence identity between human and other species in the range $58-70 \%$. The C-terminal extension of A2PI is characterized by four totally and two partially conserved Lys residues, of which the C-terminal Lys ${ }^{452}$ is most likely the main binding partner to the LBS in the Pgn kringle domains and Lys ${ }^{436}$ seems to exhibit a cooperative effect [32, 44]. In contrast, Wang et al. [33, 124] emphasized that Lys ${ }^{436}$ is the main binding partner and Lys ${ }^{452}$ has no significant influence on the binding to the LBS in the Pgn kringle domains.

A2PI is the main physiological inhibitor of Plm, the main component of the fibrinolytic system, but A2PI also inhibits chymotrypsin and trypsin. Kinetic data show a two-step reaction for the rapid inhibition of Plm: a reversible second order reaction $\left(\mathrm{k}_{1}\right.$ about $3.8 \pm$ $\left.0.4 \times 10^{7} \mathrm{M}^{-1} \mathrm{~s}^{-1}\right)$ followed by an irreversible first-order reaction $\left(\mathrm{k}_{2}\right.$ about $\left.4.2 \pm 0.4 \times 10^{6} \mathrm{M}^{-1} \mathrm{~s}^{-1}\right)$ [31, 125128]. In the case of chymotrypsin the reactive bond in the $\mathrm{RCL}$ is moved one position further down to the C-terminus of A2PI, to $\mathrm{Met}^{365}-\mathrm{Ser}^{366}$, and the association constant $\left(\mathrm{K}_{\mathrm{a}}\right)$ for inhibiting bovine chymotrypsin is $6.7 \times$ $10^{5} \mathrm{M}^{-1} \mathrm{~s}^{-1}$ [129].

Defects in the SERPINF2 gene result in A2PI deficiency (MIM 262850), an autosomal recessive disorder causing severe haemorrhagic diathesis, an unusual susceptibility to bleeding ([130, 131].

$\alpha_{2}$-Macroglobulin [132]

Human $\alpha_{2} \mathrm{M}$ (P01023; concentration in plasma about $1,200 \mathrm{mg} \mathrm{l}^{-1}$ ) is a member of the protease inhibitor I39 family. It is primarily synthesized in the liver [133]. The $\alpha_{2} \mathrm{M}$ gene $(A 2 M$, about $48 \mathrm{~kb})$ is located on chromosome 12p13.3-p12.3 and consists of 36 exons in the range 21-229 bp [134]. Mature $\alpha_{2} \mathrm{M}$ is a large single-chain plasma glycoprotein (about 10\% CHO) of 1,451 amino acids containing eight $\mathrm{N}$-glycosylation sites at $\mathrm{Asn}^{32}, \mathrm{Asn}^{47}, \mathrm{Asn}^{224}$, $\mathrm{Asn}^{373}, \mathrm{Asn}^{387}, \mathrm{Asn}^{846}, \mathrm{Asn}^{968}$, and $\mathrm{Asn}^{1401}$ [135]. In plasma, $\alpha_{2} \mathrm{M}$ is present as a tetramer (about $720 \mathrm{kDa}$ ) composed of two noncovalently associated dimers oriented in an antiparallel fashion, and the two monomers in the dimers are held together covalently by two interchain disulfide bridges $\left(\mathrm{Cys}^{255}-\mathrm{Cys}^{408}\right.$, $\left.\mathrm{Cys}^{408}-\mathrm{Cys}^{255}\right)$ [136]. $\mathrm{Gln}^{670}$ and $\mathrm{Gln}^{671}$ are potential crosslinking sites, with the side-chains of Lys residues in other proteins forming isopeptide bonds comparable to $\mathrm{Gln}^{2}$ in Asn-A2PI (see section $\alpha_{2}$-Antiplasmin or $\alpha_{2}$-plasmin inhibitor). Like the structurally related complement components C3 (P01024) and C4 (P0C0L4, P0C0L5), $\alpha_{2} \mathrm{M}$ contains a reactive isoglutamyl cysteine thioester bond Cys ${ }^{949}-\mathrm{Gly}-\mathrm{Glu}-\mathrm{Gln}^{952}$. $\alpha_{2} \mathrm{M}$ contains a 'bait' region of 39 amino acids (Pro ${ }^{667}-\mathrm{Thr}^{705}$ ) with three short inhibitory sequence segments (Arg ${ }^{681}-\mathrm{Glu}^{686}$, $\mathrm{Arg}^{696}-\mathrm{Val}^{700}, \mathrm{Thr}^{707}-\mathrm{Phe}^{712}$ ) [137].

$\alpha_{2} \mathrm{M}$ is a general inhibitor of all four types of proteases and acts as a scavenger. Limited proteolysis in the 'bait' region of $\alpha_{2} \mathrm{M}$ at specific cleavage sites by the active protease induces a large conformational change in $\alpha_{2} \mathrm{M}$, resulting in the trapping of the protease in a large central cavity [135]. Concomitantly, the internal thioester bond is cleaved, which mediates the covalent binding of $\alpha_{2} \mathrm{M}$ to the protease. In the case of Plm, it appears that proteolysis and conformational changes in $\alpha_{2} \mathrm{M}$ are limited to one of the two subunits and the association constant $\mathrm{K}_{\mathrm{a}}$ for Plm is $1.3 \times 10^{5} \mathrm{M}^{-1} \mathrm{~s}^{-1}[138]$.

$\alpha_{2} \mathrm{M}$ seems to be associated with Alzheimer disease (MIM 103950) and a deletion in exon 18 seems to be the cause of an increased risk of Alzheimer disease [139]. 


\section{Plasminogen activator inhibitors}

There are two main physiological plasminogen activator inhibitors, PAI-1 and PAI-2, which are more or less directly involved in the inhibition process of the main plasminogen activators, tPA and uPA. In addition, neuroserpin (predominantly expressed in the brain) mainly inhibits tPA, uPA, and Plm, whereas glia-derived nexin has a broader specificity, but also inhibits uPA and Plm.

Plasminogen activator inhibitor 1

Human PAI-1 (P05121; concentration in plasma about $20 \mu \mathrm{g} \mathrm{l}^{-1}$, variable) is a member of the serpin superfamily. It is produced by a variety of cells such as endothelial cells, smooth muscle cells, and liver cells [140]. PAI-1 is a singlechain plasma glycoprotein (13\% CHO) of $50 \mathrm{kDa}$ (379 amino acids) containing three $\mathrm{N}$-glycosylation sites at $\mathrm{Asn}^{209}, \mathrm{Asn}^{265}$, and $\mathrm{Asn}^{329}$ (potential) [141]. The PAI-1 gene (SERPINE1, $12.2 \mathrm{~kb}$ ) is located on chromosome 7q21.3-q22 and consists of nine exons [142]. The scissile peptide bond $\mathrm{P} 1-\mathrm{P}^{\prime}$ is located at $\mathrm{Arg}^{346}-\mathrm{Met}^{347}[141,143]$. The 3-D structure of PAI-1 in complex with two inhibitory RCL pentapeptides (Ac-TVASS- $\mathrm{NH}_{2}$ ) was determined by $\mathrm{X}$-ray diffraction (1A7C) and is shown in Fig. 10 [144]. The

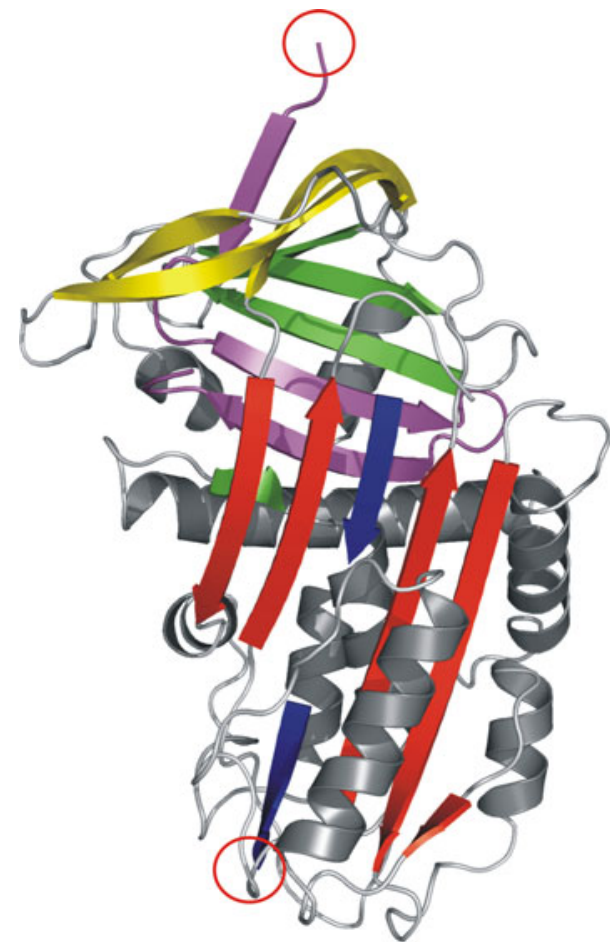

Fig. 10 3-D structure of human PAI-1 in complex with two inhibitory RCL pentapeptides (Ac-TVASS- $\mathrm{NH}_{2}$ ) determined by $\mathrm{X}$-ray diffraction $(1 \mathrm{~A} 7 \mathrm{C},[144])$. The two pentapeptides (blue) bind between $\beta$-strands 3 and 5 in $\beta$-sheet A (red). The cleaved C-terminal region is shown in magenta and the cleaved ends of the reactive peptide bond are located on either side of the molecule (red circles) two pentapeptides (in blue) bind between the space of $\beta$-strands 3 and 5 in $\beta$-sheet $\mathrm{A}$ (in red). This prevents the insertion of the RCL into $\beta$-sheet $\mathrm{A}$ and as a consequence abolishes the inhibitory reaction with the target serine protease. This form of PAI-1 exhibits the typical structural features of cleaved serpins with the cleaved regions of the RCL on either side of the molecule (red circles) and the cleaved C-terminal region is shown in magenta.

PAI-1 primarily inhibits tPA and uPA with second-order rate constants of $2.5-4 \times 10^{7} \mathrm{M}^{-1} \mathrm{~s}^{-1}$ for two-chain tPA and $1 \times 10^{7} \mathrm{M}^{-1} \mathrm{~s}^{-1}$ for uPA, thus regulating fibrinolysis by limiting the Plm production. In addition, PAI-1 also inhibits other serine proteases, but at much slower rates, e.g. thrombin $\left(1.1 \times 10^{3} \mathrm{M}^{-1} \mathrm{~s}^{-1}\right), \quad$ Plm $\left(6.6 \times 10^{5} \mathrm{M}^{-1} \mathrm{~s}^{-1}\right.$, bovine PAI-1), trypsin $\left(7 \times 10^{6} \mathrm{M}^{-1} \mathrm{~s}^{-1}\right)$, and activated protein $\mathrm{C}$ [145-148]. PAI-1 is bound to vitronectin (P04004) in plasma and in the extracellular matrix [149]. Vitronectin and also heparin enhance the inhibition rate constant of PAI- 1 for thrombin by a factor of up to 200-fold [150]. In the case of a vascular injury, activated platelets can increase the low plasma concentration of PAI-1 by a factor of 10 [151, 152].

Defects in the SERPINE1 gene are the cause of PAI-1 deficiency (MIM 173360), characterized by an abnormal bleeding tendency [153]. High levels of PAI-1 seem to be associated with myocardial infarction [154].

Plasminogen activator inhibitor $2[155,156]$

Human PAI-2 (P05120; concentration in plasma $<5 \mu \mathrm{g} \mathrm{l}^{-1}$, only detectable during pregnancy [157]) is a member of the serpin superfamily. It is produced by epithelial cells, monocytes and macrophages, and keratinocytes [158-162]. Due to the lack of a proper signal sequence (it contains an inefficient internal signal sequence [163]) PAI-2 is not efficiently secreted and therefore accumulates intracellularly as a nonglycosylated 47-kDa protein [164]. A small portion of singlechain PAI-2 is secreted via a facultative translocation pathway [165] as a 60-kDa (415 amino acids) plasma glycoprotein containing three potential $\mathrm{N}$-glycosylation sites at $\mathrm{Asn}^{75}, \mathrm{Asn}^{115}$, and $\mathrm{Asn}^{339}$, and one assigned disulfide bridge $\left(\mathrm{Cys}^{5}-\mathrm{Cys}^{405}\right)$ [156]. The PAI-2 gene (SERPINB2, $16.4 \mathrm{~kb}$ ) is located on chromosome 18q21.2-q22 and contains eight exons $[166,167]$. The scissile peptide bond $\mathrm{P} 1-\mathrm{P} 1^{\prime}$ is located at $\mathrm{Arg}^{380}-\mathrm{Thr}^{381}$ [168]. As $\mathrm{Gln}^{2}$ in A2PI, $\mathrm{Gln}^{83}$, $\mathrm{Gln}^{84}$, and $\mathrm{Gln}^{86}$ located in the C-D interhelical domain in PAI-2 (in other serpins corresponding to the C-D loop) can form isopeptide bonds with Lys residues in the $\mathrm{A} \alpha$ chain of fibrinogen, i.e. $\mathrm{Lys}^{148}$, $\mathrm{Lys}^{176}$, $\mathrm{Lys}^{183}$, $\mathrm{Lys}^{230}$, $\mathrm{Lys}^{413}$, and Lys $^{457}$ catalysed by coagulation factor XIIIa $[169,170]$. The 3-D structure of a deletion mutant (deletion of loop $\mathrm{Asn}^{66}$ $\mathrm{Gln}^{98}$ ) of PAI-2 was determined by X-ray diffraction (1BY7) and is shown in Fig. 11 [171]. This deletion mutant represents the stressed state of a serpin with a disordered structure of the 


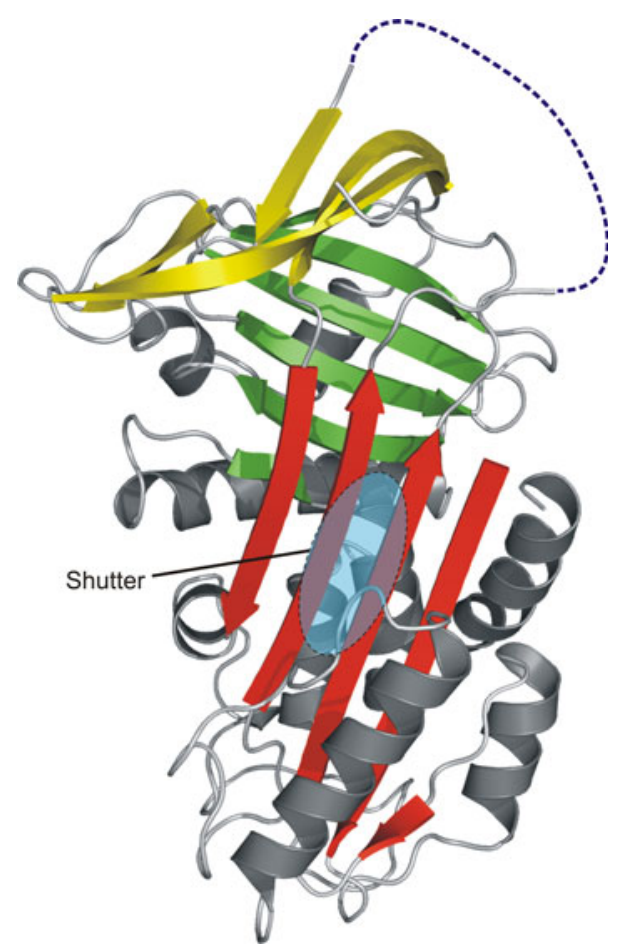

Fig. 11 3-D structure of a deletion mutant of human PAI-2 determined by X-ray diffraction (1BY7, [171]). The reconstructed $\mathrm{RCL}$ is shown as a dashed blue line and the shutter region located beneath $\beta$-sheet $\mathrm{A}$ (red) is shown as a blue-shaded oval

RCL (the reconstructed RCL is represented as dashed, blue line). A buried cluster of polar amino acids beneath $\beta$-sheet $\mathrm{A}$ (in red), the so-called shutter region (indicated by a blueshaded oval) stabilizes the stressed as well as the relaxed forms of serpins. As expected, the insertion of the RCL into $\beta$-sheet $\mathrm{A}$ is essential for the inhibition reaction.

PAI-2 is an efficient inhibitor of tPA and uPA with second-order rate constants of $0.8-1.2 \times 10^{4} \mathrm{M}^{-1} \mathrm{~s}^{-1}$ for two-chain tPA and 2.4-2.7 $\times 10^{6} \mathrm{M}^{-1} \mathrm{~s}^{-1}$ for uPA [172]. PAI-2 is only detectable in plasma during pregnancy and probably has a role in maintaining the placenta or in embryonic development [157]. As mentioned above, only a small portion of PAI-2 is secreted. Intracellular PAI-2 exhibits other functions than inhibition of uPA and tPA, e.g. PAI-2 influences cell proliferation and cell differentiation, inhibits apoptosis, and alters gene expression.

Little is known of precisely described diseases related to PAI-2 defects (MIM 173390).

\section{Neuroserpin [173-175]}

Neuroserpin (Q99574; usually not detectable in plasma) is a member of the serpin superfamily. It is predominantly expressed in the brain $[176,177]$. Neuroserpin is a singlechain glycoprotein of $55 \mathrm{kDa}$ (394 amino acids) containing three potential N-glycosylation sites at $\mathrm{Asn}^{141}, \mathrm{Asn}^{305}$, and

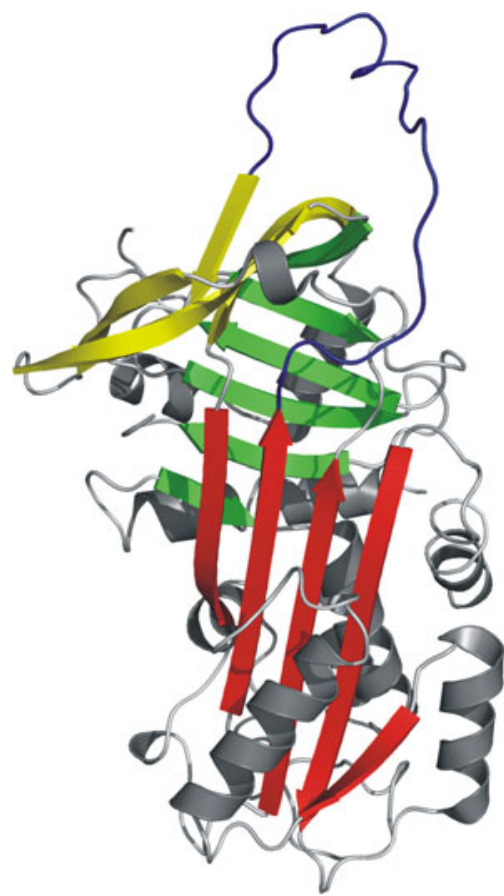

Fig. 12 3-D structure of uncleaved, native human neuroserpin determined by X-ray diffraction (3F5N, 3F02, [180]). Neuroserpin contains the typical structural elements of uncleaved, native serpins: three $\beta$-sheets (red, green, yellow), nine $\alpha$-helices (grey), and the exposed RCL (blue)

$\mathrm{Asn}^{385}$ [178, 179]. The neuroserpin gene (SERPINI1, $89.8 \mathrm{~kb}$ ) is located on chromosome $3 \mathrm{q} 26.1$ and consists of nine exons $[176,177]$. The scissile peptide bond $\mathrm{P} 1-\mathrm{P}^{\prime}{ }^{\prime}$ is located at $\mathrm{Arg}^{346}-\mathrm{Met}^{347}$ [176]. The 3-D structure of uncleaved, native neuroserpin was determined by X-ray diffraction (3F5N, 3F02) and is shown in Fig. 12 [180]. It contains the expected elements of the core structure of serpins: three $\beta$-sheets (shown in red, green, and yellow), nine $\alpha$-helices (in grey), and the exposed RCL (in blue).

tPA, uPA, and Plm have been identified as the main targets of neuroserpin activity [176, 180]. The corresponding association constants $\mathrm{K}_{\mathrm{a}}$ for recombinant neuroserpin (chicken) are: (1) $1.5 \pm 0.2 \times 10^{5} \mathrm{M}^{-1} \mathrm{~s}^{-1}$ (sc-tPA), (2) $4.7 \pm 0.8 \times$ $10^{4} \mathrm{M}^{-1} \mathrm{~s}^{-1}$ (uPA), and (3) $1.1 \pm 0.1 \times 10^{5} \mathrm{M}^{-1} \mathrm{~s}^{-1}$ (Plm) [181].

Neuroserpin seems to be involved in the formation and reorganization of synaptic connections and may be involved in the protection of neurons from cell damage by tPA. Defects in the SERPINI1 gene are the cause of familial encephalopathy characterized by neuroserpin inclusion bodies [177, 182].

\section{Glia-derived nexin}

Human glia-derived nexin (P07093) is a member of the serpin superfamily. It is synthesized by fibroblasts, heart 
muscle cells, and kidney epithelial cells, and also in the brain [183]. Glia-derived nexin is a single-chain plasma glycoprotein (about 6\% CHO) of $43 \mathrm{kDa}$ (379 amino acids) containing two potential $\mathrm{N}$-glycosylation sites at $\mathrm{Asn}^{99}$ and $\mathrm{Asn}^{140}$ [184]. The scissile peptide bond $\mathrm{P} 1-\mathrm{P} 1^{\prime}$ is located at $\mathrm{Arg}^{346}-\mathrm{Ser}^{347}$ [185]. The glia-derived nexin gene (SERPINE2) is located on chromosome 2q33-q35 containing nine exons [186, 187].

Glia-derived nexin has a broad specificity but it primarily inhibits trypsin, thrombin, uPA, and Plm. It seems to be the most important physiological regulator of $\alpha$-thrombin in tissues [183]. The association constants $K_{a}$ are: (1) $4.2 \pm 0.4 \times 10^{6} \mathrm{M}^{-1} \mathrm{~s}^{-1}$ (trypsin), (2) $6.0 \pm 1.3 \times$ $10^{5} \mathrm{M}^{-1} \mathrm{~s}^{-1}$ (thrombin), (3) $1.5 \pm 0.1 \times 10^{5} \mathrm{M}^{-1} \mathrm{~s}^{-1}$ (uPA), and (4) $1.3 \pm 0.1 \times 10^{5} \mathrm{M}^{-1} \mathrm{~s}^{-1}$ (Plm) $[184,185]$.

Diseases related to defects in the SERPINE2 gene are not very well understood (MIM 177010). However, the SERPINE2 gene seems to be associated with chronic obstructive pulmonary disease [187].

\section{Concluding remarks}

The plasmin-antiplasmin system contains two main protein families, namely multidomain serine proteases represented by Pgn, tPA, and UPA, and serpins represented primarily by A2PI as well as PAI-1 and PAI-2. The data provide evidence that the noncatalytic domains in multidomain serine proteases such as kringles, FN1, or EGF-like domains mediate efficient binding to the target structures, facilitating an efficient cleavage reaction of the corresponding serine protease which is usually strictly limited to the intended site. Thus, the described multidomain serine proteases in the plasmin-antiplasmin system are welladapted proteins which efficiently fulfil their tasks. The data provided show that the plasmin-antiplasmin system as a every complex system is tightly regulated by a series of physiological inhibitors, in this case primarily by serpins such as A2PI, PAI-1, and PAI-2. Also these inhibitors are very well adapted to their regulatory task.

\section{References}

1. Schaller J, Gerber S, Kämpfer U, Lejon S, Trachsel C (2008) Human blood plasma proteins: structure and function. Wiley, Chichester

2. Gerber SS (2009) The human $\alpha_{2}$-plasmin inhibitor: functional characterization of the unique plasmin(ogen)-binding region. Inaugural dissertation, University of Bern, Switzerland

3. Waisman DM (2003) Plasminogen: structure, activation, and regulation. Kluwer Academic/Plenum Publishers, New York

4. Syrovets T, Simmet T (2004) Novel aspects and new roles of the serine protease plasmin. Cell Mol Life Sci 61:873-885
5. Myöhänen H, Vaheri A (2004) Regulation and interaction in the activation of cell-associated plasminogen. Cell Mol Life Sci 61:2840-2858

6. Castellino FJ, Ploplis VA (2005) Structure and function of the plasminogen/plasmin system. Thromb Haemost 93:647-654

7. Raum D, Marcus G, Alper CA, Levey R, Taylor PD, Starzl TE (1980) Synthesis of human plasminogen by the liver. Science 208:1036-1037

8. Forsgren M, Råden B, Israelsson M, Larsson K, Hedén LO (1987) Molecular cloning and characterization of a full-length cDNA clone for human plasminogen. FEBS Lett 213:254-260

9. Murray JC, Buetow KH, Donovan M, Hornung S, Motulsky AG, Disteche C, Dyer K, Swisshelm K, Anderson J, Giblett E, Sadler E, Eddy R, Shows TB (1987) Linkage disequilibrium of plasminogen polymorphisms and assignment of the gene to human chromosome 6q26-6q27. Am J Hum Genet 40:338-350

10. Petersen TE, Martzen MR, Ichinose A, Davie EW (1990) Characterization of the gene for human plasminogen, a key proenzyme in the fibrinolytic system. J Biol Chem 265:6104-6111

11. Ljinen HR, Hoylaerts M, Collen D (1980) Isolation and characterization of a human plasma protein with affinity for the lysine binding sites in plasminogen. J Biol Chem 255:10214-10222

12. Jones AL, Hulett MD, Altin JG, Hogg P, Parish CR (2004) Plasminogen is tethered with high affinity to the cell surface by the plasma protein, histidine-rich glycoprotein. J Biol Chem 279:38267-38276

13. Tordai H, Bányai L, Patthy L (1999) The PAN module: the Nterminal domains of plasminogen and hepatocyte growth factor are homologous with the apple domains of the prekallikrein family and with a novel domain found in numerous nematode proteins. FEBS Lett 461:63-67

14. Sottrup-Jensen L, Claeys H, Zajdel M, Petersen TE, Magnusson S (1978) The primary structure of human plasminogen: isolation of two lysine-binding fragments and one 'mini-' plasminogen (MW 38,000) by elastase-catalyzed-specific limited proteolysis. In: Davidson JF, Rowan RM, Samama MM, Desnoyers PC (eds) Progress in chemical fibrinolysis and thrombolysis, vol 3. Raven Press, New York, pp 191-209

15. Wang X, Lin X, Loy JA, Tang J, Zhang XC (1998) Crystal structure of the catalytic domain of human plasmin complexed with streptokinase. Science 281:1662-1665

16. Hayes ML, Castellino FJ (1979) Carbohydrate of the human plasminogen variants. I. Carbohydrate composition, glycopeptide isolation, and characterization. J Biol Chem 254:8768-8771

17. Hayes ML, Castellino FJ (1979) Carbohydrate of the human plasminogen variants. II. Structure of the asparagine-linked oligosaccharide unit. J Biol Chem 254:8772-8776

18. Hayes ML, Castellino FJ (1979) Carbohydrate of the human plasminogen variants. III. Structure of the O-glycosidically linked oligosaccharide unit. J Biol Chem 254:8777-8780

19. Marti T, Schaller J, Rickli EE, Schmid K, Kamerling JP, Gerwig GJ, van Halbeek H, Vliegenthart JFG (1988) The N- and O-linked carbohydrate chains of human, bovine and porcine plasminogen. Species specificity in relation to sialylation and fucosylation patterns. Eur J Biochem 173:57-63

20. Pirie-Sheperd SR, Stevens RD, Andon NL, Enghild JJ, Pizzo SV (1997) Evidence for a novel O-linked sialylated trisaccharide on Ser-248 of human plasminogen 2. J Biol Chem 272:7408-7411

21. Wang H, Prorok M, Bretthauer RK, Castellino FJ (1997) Serine578 is a major phosphorylation locus in human plasma plasminogen. Biochemistry 36:8100-8116

22. Violand BN, Castellino FJ (1976) Mechanism of the urokinasecatalyzed activation of human plasminogen. J Biol Chem 251:3906-3912 
23. Danø K, Andreasen PA, Grøndahl-Hansen J, Kristensen P, Nielsen LS, Skriver L (1985) Plasminogen activators, tissue degradation, and cancer. Adv Cancer Res 44:139-266

24. Robbins KC, Summaria L, Hsieh B, Shah RJ (1967) The peptide chains of human plasmin. Mechanism of activation of human plasminogen to plasmin. J Biol Chem 242:2333-2342

25. Wang X, Terzyan S, Tang J, Loy JA, Lin X, Zhang XC (2000) Human plasminogen catalytic domain undergoes an unusual conformational change upon activation. J Mol Biol 295:903-914

26. Schick LA, Castellino FJ (1974) Direct evidence for the generation of an active site in the plasminogen moiety of the streptokinase-human plasminogen activator complex. Biochem Biophys Res Commun 57:47-54

27. Kowalska-Loth B, Zakrzewski K (1975) The activation by staphylokinase of human plasminogen. Acta Biochim Pol 22:327-339

28. Ramesh V, Petros AM, Llinás M, Tulinsky A, Park CH (1987) Proton magnetic resonance study of lysine-binding to the kringle 4 domain of human plasminogen. The structure of the binding site. J Mol Biol 198:481-498

29. Mathews II, Vanderhoff-Hanavar P, Castellino FJ, Tulinsky A (1996) Crystal structures of the recombinant kringle 1 domain of human plasminogen in complexes with the ligands epsilonaminocaproic acid and trans-4-(aminomethyl)cyclohexane-1carboxylic acid. Biochemistry 35:2567-2576

30. Suenson E, Thorsen S (1981) Secondary-site binding of gluplasmin, lys-plasmin and miniplasmin to fibrin. Biochem $\mathrm{J}$ 197:619-628

31. Wiman B, Lijnen HR, Collen D (1979) On the specific interaction between the lysine-binding sites in plasmin and complementary sites in alpha2-antiplasmin and in fibrinogen. Biochim Biophys Acta 579:142-154

32. Frank PS, Douglas JT, Locher M, Llinás M, Schaller J (2003) Structural/functional characterization of the $\alpha 2$-plasmin inhibitor C-terminal peptide. Biochemistry 42:1078-1085

33. Wang H, Yu A, Wiman B, Pap S (2003) Identification of amino acids in antiplasmin involved in its noncovalent 'lysine-bindingsite'-dependent interaction with plasmin. Eur $\mathrm{J}$ Biochem 270:2023-2029

34. Ponting CP, Marshall JM, Cederhoilm Williams SA (1992) Plasminogen: a structural review. Blood Coagul Fibrinolysis 3:605-614

35. Berg A, Sjöbring U (1993) PAM, a novel plasminogen-binding protein from Streptococcus pyogenes. J Biol Chem 268:25417-25424

36. Carlsson Wistedt A, Kotarsky H, Marti D, Ringdahl U, Castellino FJ, Schaller J, Sjöbring U (1998) Kringle 2 mediates high affinity binding of plasminogen to an internal sequence in streptococcal surface protein PAM. J Biol Chem 273:24420-24424

37. Miles LA, Dahlberg CM, Plow EF (1988) The cell binding domains of plasminogen and their function plasma. J Biol Chem 263:11928-11934

38. Marti D, Schaller J, Ochensberger B, Rickli EE (1994) Expression, purification and characterization of the recombinant kringle 2 and kringle 3 domains of human plasminogen and analysis of their binding affinities for $\omega$-aminocarboxylic acids. Eur J Biochem 219:455-462

39. Söhndel S, Hu C-K, Marti D, Affolter M, Schaller J, Llinås M, Rickli EE (1996) Recombinant gene expression and 1H NMR characteristics of the kringle $(2+3)$ supermodule: spectroscopic/functional individuality of plasminogen kringle domains. Biochemistry 35:2357-2364

40. Bürgin J, Schaller J (1999) Expression, isolation and characterization of a mutated human plasminogen kringle 3 with a functional lysine binding site. Cell Mol Life Sci 55:135-141
41. Marti DN, Hu C-K, An SSA, von Haller P, Schaller J, Llinás M (1997) Ligand preferences of kringle 2 and homologous domains of human plasminogen: canvassing weak, intermediate, and high-affinity binding sites by $1 \mathrm{H}-\mathrm{NMR}$. Biochemistry 36:11591-11604

42. Marti DN, Schaller J, Llinás M (1999) Solution structure and dynamics of the plasminogen kringle-2-AMCHA complex: 3(1)helix in homologous domains. Biochemistry 38:15741-15755

43. Chang Y, Mochalkin I, McCance SG, Chen B, Tulinsky A, Castellino FJ (1998) Structure and ligand binding determinants of the recombinant kringle 5 domain of human plasminogen. Biochemistry 37:3258-3271

44. Gerber SS, Lejon S, Locher M, Schaller J (2010) The human $\alpha 2$-plasmin inhibitor: functional characterization of the unique plasmin(ogen)-binding region. Cell Mol Life Sci 67:1505-1518

45. Tranqui L, Prandini M-H, Chapel A (1979) The structure of plasminogen studied by electron microscopy. Biol Cellul 34:39-42

46. Weisel JW, Nagaswami C, Korsholm B, Petersen LC, Suenson E (1994) Interactions of plasminogen with polymerizing fibrin and its derivatives, monitored with a photoaffinity cross-linker and electron microscopy. J Mol Biol 235:1117-1135

47. Abad MC, Arni RK, Grella DK, Castellino FJ, Tulinsky A, Geiger JH (2002) The X-ray crystallographic structure of the angiogenesis inhibitor angiostatin. J Mol Biol 318:1009-1017

48. Walker JB, Nesheim ME (1999) The molecular weights, mass distribution, chain composition, and structure of soluble fibrin degradation products released from a fibrin clot perfused with plasmin. J Biol Chem 274:5201-5212

49. Mak TW, Rutledge G, Sutherland DJ (1976) Androgen-dependent fibrinolytic activity in a murine mammary carcinoma (Shionogi SC-115 cells) in vitro. Cell 7:223-226

50. Strickland S, Reich E, Sherman MI (1976) Plasminogen activator in early embryogenesis: enzyme production by trophoblast and parietal endoderm. Cell 9:231-240

51. Gross JL, Moscatelli D, Rifkin DB (1983) Increased capillary endothelial cell protease activity in response to angiogenic stimuli in vitro. Proc Natl Acad Sci U S A 80:2623-2627

52. Ossowski L, Reich E (1983) Antibodies to plasminogen activator inhibit human tumor metastasis. Cell 35:611-619

53. Nielsen LS, Kellerman GM, Behrendt N, Picone R, Danø K, Blasi F (1988) A 55,000-60,000 Mr receptor protein for urokinase-type plasminogen activator. Identification in human tumor cell lines and partial purification. $\mathrm{J}$ Biol Chem 263:2358-2363

54. Schäfer BM, Maier K, Eickhoff U, Todd RF, Kramer MD (1994) Plasminogen activation in healing human wounds. Am J Pathol 144:1269-1280

55. Netzel-Arnett S, Mitola DJ, Yamada SS, Chrysovergis K, Holmbeck K, Birkedal-Hansen H, Bugge TH (2002) Collagen dissolution by keratinocytes requires cell surface plasminogen activation and matrix metalloproteinase activity. J Biol Chem 277:45154-45161

56. Bonnefoy A, Legrand C (2000) Proteolysis of subendothelial adhesive glycoproteins (fibronectin, thrombospondin, and von Willebrand factor) by plasmin, leukocyte cathepsin G, and elastase. Thromb Res 98:323-332

57. Nakagami Y, Abe K, Nishiyama N, Matsuki N (2000) Laminin degradation by plasmin regulates long-term potentiation. J Neurosci 20:2003-2010

58. Zeibdawi AR, Pryzdial EL (2001) Mechanism of factor Va inactivation by plasmin. Loss of $\mathrm{A} 2$ and $\mathrm{A} 3$ domains from a $\mathrm{Ca} 2+-$ dependent complex of fragments bound to phospholipid. J Biol Chem 276:19929-19936

59. Hamilton KK, Fretto LJ, Grierson DS, McKee PA (1985) Effects of plasmin on von Willebrand factor multimers. 
Degradation in vitro and stimulation of release in vivo. J Clin Invest 76:261-270

60. Seligsohn U, Lubetsky A (2001) Genetic susceptibility to venous thrombosis. New Engl J Med 344:1222-1231

61. Ichinose A, Espling ES, Takamatsu J, Saito H, Shinmyozu K, Maruyama I, Petersen TE, Davie EW (1991) Two types of abnormal genes for plasminogen in families with a predisposition for thrombosis. Proc Natl Acad Sci U S A 88:115-119

62. Schuster V, Seregard S (2003) Ligneous conjunctivitis. Surv Ophthalmol 48:369-388

63. Levin EG (1983) Latent tissue plasminogen activator produced by human endothelial cells in culture: evidence for an enzymeinhibitor complex. Proc Natl Acad Sci U S A 80:6804-6808

64. Sappino A-P, Madani R, Huarte J, Belin D, Kiss JZ, Wohlwend A, Vassalli J-D (1993) Extracellular proteolysis in the adult murine brain. J Clin Invest 92:679-685

65. Pfeiffer G, Schmidt M, Strube K-H, Geyer R (1989) Carbohydrate structure of recombinant human uterine tissue plasminogen activator expressed in mouse epithelial cells. Eur J Biochem 186:273-286

66. Harris RJ, Leonard CK, Guzzetta AW, Spellman MW (1991) Tissue plasminogen activator has an O-linked fucose attached to threoine-61 in the epidermal growth factor domain. Biochemistry 30:2311-2314

67. Pennica D, Holmes WE, Kohr WJ, Harkins RN, Vehar GA, Ward CA, Bennett WF, Yelverton E, Seeburg PH, Heyneker HL, Goeddel DV, Collen D (1983) Cloning and expression of human tissue-type plasminogen activator cDNA in E. coli. Nature 301:214-221

68. Ny T, Elgh F, Lund B (1984) The structure of the human tissuetype plasminogen activator gene: correlation of introns and exon structures to functional and structural domains. Proc Natl Acad Sci U S A 81:5355-5359

69. Fisher R, Waller EK, Grossi G, Thompson D, Tizard R, Schleuning W-D (1985) Isolation and characterization of the human tissue-type plasminogen activator structural gene including its 5' flanking region. J Biol Chem 260:11223-11230

70. Loscalzo J (1988) Structural and kinetic comparison of recombinant human single- and two-chain tissue plasminogen activator. J Clin Invest 82:1391-1397

71. Collen D, Lijnen HR (1991) Basic and clinical aspects of fibrinolysis and thrombolysis. Blood 78:3114-3124

72. Byeon IJ, Llinás M (1991) Solution structure of the tissue-type plasminogen activator kringle 2 domain complexed to 6-aminohexanoic acid, an antifibrinolytic drug. J Mol Biol 222:1035-1051

73. de Vos AM, Ultsch MH, Kelley RF, Padmanabhan K, Tulinsky A, Westbrook ML, Kossiakoff AA (1992) Crystal structure of the kringle 2 domain of tissue plasminogen activator at $2.4 \AA$ resolution. Biochemistry 31:270-279

74. Smith BO, Downing AK, Driscoll PC, Dudgeon TJ, Campbell ID (1995) The solution structure and backbone dynamics of the fibronectin type I and epidermal growth factor-like pair of modules of tissue-type plasminogen activator. Structure 3:823-833

75. Bennett WF, Paoni NF, Keyt BA, Botstein D, Jones AJ, Presta L, Wurm FM, Zoller MJ (1991) High resolution analysis of functional determinants on human tissue-type plasminogen activator. J Biol Chem 266:5191-5201

76. de Vries C, Vaerman H, Pannekoeck H (1989) Identification of the domains of tissue-type plasminogen activator involved in the augmented binding to fibrin after limited digestion with plasmin. J Biol Chem 264:12604-12610

77. Hoylaerts M, Rijken DC, Lijnen HR, Collen D (1982) Kinetics of the activation of plasminogen by human tissue plasminogen activator. Role of fibrin. J Biol Chem 257:2912-2919
78. Lamba D, Bauer M, Huber R, Fischer S, Rudolph R, Kohnert U, Bode W (1996) The 2.3 A crystal structure of the catalytic domain of recombinant two-chain human tissue-type plasminogen activator. J Mol Biol 258:117-135

79. Renatus M, Engh RA, Stubbs MT, Huber R, Fischer S, Kohnert U, Bode W (1997) Lysine 156 promotes the anomalous proenzyme activity of tPA: X-ray crystal structure of single-chain human tPA. EMBO J 16:4797-4805

80. Hajjar KA, Jacovina AT, Chacko J (1994) An endothelial cell receptor for plasminogen/tissue plasminogen activator I. Identity with annexin II. J Biol Chem 269:21191-21197

81. Cesarman GM, Guevara CA, Hajjar KA (1994) An endothelial cell receptor for plasminogen/tissue plasminogen activator ( $\mathrm{t}$ PA) II. Annexin-II mediated enhancement of t-PA-dependent plasminogen activation. J Biol Chem 269:21198-21203

82. Hunt BJ, Segal H (1996) Hyperfibrinolysis. J Clin Pathol 49:958

83. Bernik MB, Kwaan HC (1969) Plasminogen activator activity in cultures from human tissues. An immunological and histochemical study. J Clin Invest 48:1740-1753

84. Duffy MJ (1990) Plasminogen activators and cancer. Blood Coagul Fibrinolysis 1:681-687

85. Nielsen LS, Hansen JG, Skriver L, Wilson EL, Kaltoft K, Zeuthen J, Danø K (1982) Purification of zymogen to plasminogen activator from human glioblastoma cells by affinity chromatography with monoclonal antibody. Biochemistry 21:6410-6415

86. Wun TC, Ossowski L, Reich E (1982) A proenzyme form of human urokinase. J Biol Chem 257:7262-7268

87. Buko AM, Kentzer EJ, Petros A, Menon G, Zuiderweg ERP, Sarin VK (1991) Characterization of posttranslational fucosylation in the growth factor domain of urinary plasminogen activator. Proc Natl Acad Sci U S A 88:3992-3996

88. Franco P, Iaccarino C, Chiaradonna F, Brandazza A, Iavarone C, Mastronicola MR, Nolli ML, Stoppelli MP (1997) Phosphorylation of human pro-urokinase on Ser138/303 impairs its receptor-dependent ability to promote myelomonocytic adherence and motility. J Cell Biol 137:779-791

89. Riccio A, Grimaldi G, Verde P, Sebastio G, Boast S, Blasi F (1985) The human urokinase-plasminogen activator gene and its promotor. Nucleic Acids Res 13:2759-2771

90. Kobayashi H, Schmitt M, Goretzki L, Chucholowski N, Calvete J, Kramer M, Günzler WA, Jänicke F, Graeff H (1991) Cathepsin B efficiently activates the soluble and the tumor cell receptor-bound form of the proenzyme urokinase-type plasminogen activator (Pro-uPA). J Biol Chem 266:5147-5152

91. Steffens GJ, Günzler WA, Otting F, Frankus E, Flohe L (1982) The complete amino acid sequence of low molecular mass urokinase from human urine. Hoppe Seylers Z Physiol Chem 363:1043-1058

92. Hansen AP, Petros AM, Meadows RP, Nettesheim DG, Mazar AP, Olejniczak ET, Xu RX, Pederson TM, Henkin J, Fesik SW (1994) Solution structure of the amino-terminal fragment of urokinase-type plasminogen activator. Biochemistry 33:4847-4864

93. Stephens RW, Bokman AM, Myohanen HT, Reisberg T, Tapiovaara H, Pedersen N, Grøndahl-Hansen J, Llinás M, Vaheri A (1992) Heparin binding to the urokinase kringle domain. Biochemistry 31:7572-7579

94. Li X, Bokman AM, Llinás M, Smith RA, Dobson CM (1994) Solution structure of the kringle domain from urokinase-type plasminogen activator. J Mol Biol 235:1548-1559

95. Appella E, Robinson EA, Ulrich SJ, Stoppelli MP, Corti A, Cassani G, Blasi F (1987) The receptor-binding sequence of urokinase. A biological function for the growth-factor module of proteases. J Biol Chem 262:4437-4440 
96. Ploug M, Rahbek-Nielsen H, Ellis V, Roepstorff P, Danø K (1995) Chemical modification of the urokinase-type plasminogen activator and its receptor using tetranitromethane. Evidence for the involvement of specific tyrosine residues in both molecules during receptor-ligand interaction. Biochemistry 34:12524-12534

97. Katz BA, Sprengeler PA, Luong C, Verner E, Elrod K, Kritley M, Janc J, Spencer JR, Breitenbucher JG, Hui H, McGee D, Allen D, Martelli A, Mackman RL (2001) Engineering inhibitors highly selective for the S1 sites of Ser190 trypsin-like serine protease drug targets. Chem Biol 8:1107-1121

98. Andreasen PA, Kjøller L, Christensen L, Duffy MJ (1997) The urokinase-type plasminogen activator system in cancer metastasis: a review. Int $\mathrm{J}$ Cancer 72:1-22

99. Janciauskiene S (2001) Conformational properties of serine proteinase inhibitors (serpins) confer multiple pathophysiological roles. Biochim Biophys Acta 1535:221-235

100. Silverman GA, Bird PI, Carrell RW, Church FC, Coughlin PB, Gettins PGW, Irving IA, Lomas DA, Luke CJ, Moyer RW, Pemberton PA, Remold-O'Donnell E, Salvesen GS, Travis J, Whisstock JC (2001) The serpins are an expanding superfamily of structurally similar but functionally diverse proteins. Evolution, mechanism of inhibition, novel functions, and a revised nomenclature. J Biol Chem 276:33293-33296

101. Law RH, Zhang Q, McGowan S, Buckle AM, Silverman GA, Wong W, Rosado CJ, Langendorf CG, Pike RN, Bird PI, Whisstock JC (2006) An overview of the serpin superfamily. Genome Biol 7:216-226

102. Gettins PG, Olson ST (2009) Exosite determinants of serpin specificity. J Biol Chem 284:20441-20445

103. Irving JA, Pike RN, Lesk AM, Whisstock JC (2000) Phylogeny of the serpin superfamily: implications of patterns of amino acid conservation for structure and function. Genome Res $10: 845-864$

104. van Gent D, Sharp P, Morgan K, Kalsheker N (2003) Serpins: structure, function and molecular evolution. Int J Biochem Cell Biol 35:1536-1547

105. Gettins PG (2000) Keeping the serpin machine running smoothly. Genome Res 10:1833-1835

106. Coughlin PB (2005) Antiplasmin: the forgotten serpin? FEBS J 272:4852-4857

107. Favier R, Aoki N, de Moerloose P (2001) Congenital $\alpha 2$-plasmin inhibitor deficiencies: a review. Br J Haematol 114:4-10

108. Saito H, Goodnough LT, Knowles BB, Aden DP (1982) Synthesis and secretion of $\alpha 2$-plasmin inhibitor by established human liver cell lines. Proc Natl Acad Sci U S A 79:5684-5687

109. Sumi Y, Ichikawa Y, Nakamura Y, Miura O, Aoki N (1989) Expression and characterization of pro $\alpha 2$-plasmin inhibitor. J Biochem 106:703-707

110. Ries M, Easton RL, Longstaff C, Zenker M, Morris HR, Dell A, Gaffney PJ (2002) Differences between neonates and adults in carbohydrate sequences and reaction kinetics of plasmin and $\alpha 2$ antiplasmin. Thromb Res 105:247-256

111. Locher M (2004) Strukturelle und funktionelle Untersuchungen am $\alpha$ 2-Plasmininhibitor. Inaugural dissertation, University of Bern, Switzerland

112. Christensen S, Valnickova Z, Thøgersen IB, Olsen EH, Enghild JJ (1997) Assignment of a single disulphide bridge in human alpha2-antiplasmin: implications for the structural and functional properties. Biochem J 323:847-852

113. Hortin G, Fok KF, Toren PC, Strauss AW (1987) Sulfation of a tyrosine residue in the plasmin-binding domain of $\alpha 2$-antiplasmin. J Biol Chem 262:3082-3085

114. Hirosawa S, Nakamura Y, Miura O, Sumi Y, Aoki N (1988) Organization of the human alpha 2-plasmin inhibitor gene. Proc Natl Acad Sci U S A 85:6836-6840
115. Koyama T, Koike Y, Toyota S, Miyagi F, Suzuki N, Aoki N (1994) Different NH2-terminal form with 12 additional residues of $\alpha 2$-plasmin inhibitor from human plasma and culture media of Hep G2 cells. Biochem Biophys Res Commun 200:417-422

116. Lee KN, Jackson KW, Christiansen VJ, Chung KH, McKee PA (2004) A novel plasma proteinase potentiates $\alpha 2$-antiplasmin inhibition of fibrin digestion. Blood 103:3783-3788

117. Sasaki T, Morita T, Iwanaga S (1986) Identification of the plasminogen-binding site of human alpha 2-plasmin inhibitor. J Biochem 99:1699-1705

118. Clemmensen I, Thorsen S, Müllertz S, Petersen LC (1981) Properties of three different molecular forms of the $\alpha 2$ plasmin inhibitor. Eur J Biochem 120:105-112

119. Kluft C, Los P, Jie AF, van Hinsbergh VW, Vellenga E, Jespersen J, Henny CP (1986) The mutual relationship between the two molecular forms of the major fibrinolysis inhibitor alpha-2-antiplasmin in blood. Blood 67:616-622

120. Holmes WE, Nelles L, Lijnen HR, Collen D (1987) Primary structure of human $\alpha 2$-antiplasmin, a serine protease inhibitor (serpin). J Biol Chem 262:1659-1664

121. Law RH, Sofian T, Kan WT, Horvath AJ, Hitchen CR, Langendorf CG, Buckle AM, Whisstock JC, Coughlin PB (2008) X-ray crystal structure of the fibrinolysis inhibitor alpha2-antiplasmin. Blood 111:2049-2052

122. Sakata Y, Aoki N (1982) Significance of cross-linking of $\alpha 2$-plasmin inhibitor to fibrin in inhibition of fibrinolysis and in hemostasis. J Clin Invest 69:536-542

123. Kimura S, Aoki N (1986) Cross-linking site in fibrinogen for $\alpha 2$-plasmin inhibitor. J Biol Chem 261:15591-15595

124. Wang H, Karlsson A, Sjöström I, Wiman B (2006) The interaction between plasminogen and antiplasmin variants as studied by surface plasmon resonance. Biochim Biophys Acta 1764:1730-1734

125. Christensen U, Clemmensen I (1977) Kinetic properties of the primary inhibitor of plasmin from human plasma. Biochem $\mathrm{J}$ 163:389-391

126. Wiman B, Collen D (1978) On the kinetics of the reaction between human antiplasmin and plasmin. Eur $\mathbf{J}$ Biochem 84:573-578

127. Wiman B, Collen D (1979) On the mechanism of the reaction between human alpha 2-antiplasmin and plasmin. J Biol Chem 254:9291-9297

128. Wiman B, Boman L, Collen D (1978) On the kinetics of the reaction between human antiplasmin and a low-molecularweight form of plasmin. Eur J Biochem 87:143-146

129. Potempa J, Shieh B-H, Travis J (1988) Alpha-2-antiplasmin: a serpin with two separate but overlapping reactive sites. Science 241:699-700

130. Miura O, Hirosawa S, Kato A, Aoki N (1989) Molecular basis for congenital deficiency of alpha-2-plasmin inhibitor: a frameshift mutation leading to elongation of the deduced amino acid sequence. J Clin Invest 83:1598-1604

131. Lind B, Thorsen S (1999) A novel missense mutation in the human plasmin inhibitor (alpha-2-antiplasmin) gene associated with a bleeding tendency. Br J Haematol 107:317-322

132. Sottrup-Jensen L (1989) $\alpha$-Macroglobulins: structure, shape, and mechanisms of proteinase complex formation. J Biol Chem 264:11539-11542

133. Borth W (1992) $\alpha 2$-Macroglobulin, a multifunctional binding protein with targeting characteristics. FASEB J 6:3345-3353

134. Matthijs G, Devriendt K, Cassiman J-J, van den Berghe H, Marynen P (1992) Structure of the human alpha-2-macroglobulin gene and its promotor. Biochem Biophys Res Commun 184:596-603

135. Sottrup-Jensen L, Stepanik TM, Kristensen T, Wierzbicki DM, Jones CM, Lønblad PB, Magnusson S, Petersen TE (1984) 
Primary structure of human alpha-2-macroglobulin V. The complete structure. J Biol Chem 259:8318-8327

136. Jensen PE, Sottrup-Jensen L (1986) Primary structure of human alpha-2-macroglobulin. Complete disulfide bridge assignment and localization of two interchain bridges in the dimeric proteinase binding unit. J Biol Chem 261:15863-15869

137. Sottrup-Jensen L, Lønblad PB, Stepanik TM, Petersen TE, Magnusson S, Jörnvall H (1981) Primary structure of the 'bait' region for proteinases in $\alpha 2$-macroglobulin. FEBS Lett 127:167-173

138. Steiner JP, Migliorini M, Strickland DK (1987) Characterization of the reaction of plasmin with $\alpha 2$-macroglobulin: Effect of antifibrinolytic agents. Biochemistry 26:8487-8495

139. Blacker D, Wilcox MA, Laird NM, Rodes L, Horvath SM, Go RCP, Perry R, Watson B Jr, Bassett SS, McInnis MG, Albert MS, Hyman BT, Tanzi RE (1998) Alpha-2 macroglobulin is genetically associated with Alzheimer disease. Nat Genet 19:357-360

140. Alessi MC, Peiretti F, Morange P, Henry M, Nalbone G, JuhanVague I (1997) Production of plasminogen activator inhibitor 1 by human adipose tissue: possible link between visceral fat accumulation and vascular disease. Diabetes 46:860-867

141. Pannekoek H, Veerman H, Lambers H, Diergaarde P, Verweij CL, van Zonneveld AJ, van Mourik JA (1986) Endothelial plasminogen activator inhibitor (PAI): a new member of the serpin gene family. EMBO J 5:2539-2544

142. Loskutoff DJ, Linders M, Keijer J, Veerman H, van Heerikhuizen H, Pannekoek H (1987) Structure of the human plasminogen activator inhibitor 1 gene: nonrandom distribution of introns. Biochemistry 26:3763-3768

143. Andreasen PA, Riccio A, Welinder KG, Douglas R, Sartorio R, Nielsen LS, Oppenheimer C, Blasi F, Danø K (1986) Plasminogen activator inhibitor type-1: reactive center and aminoterminal heterogeneity determined by protein and cDNA sequencing. FEBS Lett 209:213-218

144. Xue Y, Bjorquist P, Inghardt T, Linschoten M, Musil D, Sjolin L, Deinum J (1998) Interfering with the inhibitory mechanism of serpin: crystal structure of a complex formed between cleaved plasminogen activator inhibitor type 1 and a reactive-centre loop peptide. Structure 6:627-636

145. Alessi MC, Declerck PJ, De Mol M, Nelles L, Collen D (1988) Purification and characterization of natural and recombinant human plasminogen activator inhibitor-1 (PAI-1). Eur J Biochem 175:531-540

146. Lawrence D, Strandberg L, Grundstrom T, Ny T (1989) Purification of active human plasminogen activator inhibitor 1 from Escherichia coli. Comparison with natural and recombinant forms purified from eukaryotic cells. Eur J Biochem 186:523-533

147. Keijer J, Linders M, Wegman JJ, Ehrlich HJ, Mertens K, Pannekoek H (1991) On the target specificity of plasminogen activator inhibitor 1: the role of heparin, vitronectin, and the reactive site. Blood 78:1254-1261

148. Heckman CM, Loskutoff DJ (1988) Bovine plasminogen activator inhibitor 1: specificity determinations and comparison of the active, latent, and guanidine-activated forms. Biochemistry 27:2911-2918

149. Sigurdardottir O, Wiman B (1994) Identification of a PAI-1 binding site in vitronectin. Biochim Biophys Acta 1208:104-110

150. Ehrlich AJ, Gebbbink RK, keijer J, Linders M, Preissner KT, Pannekoek H (1990) Alteration of serpin specificity by a protein cofactor. Vitronectin endows plasminogen activator inhibitor 1 with thrombin inhibitory properties. J Biol Chem 265:13029-13035
151. Erickson LA, Ginsberg MH, Loskutoff DJ (1984) Detection and partial characterization of an inhibitor of plasminogen activator in human platelets. J Clin Invest 74:1465-1472

152. Juhan Vague I, Moerman B, De Cock F, Aillaud MF, Collen D (1984) Plasma levels of a specific inhibitor of tissue-type plasminogen activator (and urokinase) in normal and pathological conditions. Thromb Res 33:523-530

153. Fay WP, Parker AC, Condrey LR, Shapiro AD (1997) Human plasminogen activator inhibitor-1 (PAI-1) deficiency: characterization of a large kindred with a null mutation in the PAI-1 gene. Blood 90:204-208

154. Hamsten A, de Faire U, Walldius G, Dahlen G, Szamosi A, Landou C, Blomback M, Wiman B (1987) Plasminogen activator inhibitor in plasma: risk factor for recurrent myocardial infarction. Lancet 2:3-9

155. Medcalf RL, Stasinopoulos SJ (2005) The undecided serpin. The ins and outs of plasminogen activator inhibitor type 2. FEBS J 272:4858-4867

156. Kruithof EKO, Baker MS, Bunn CL (1995) Biological and clinical aspects of plasminogen activator inhibitor type 2. Blood 86:4007-4024

157. Lecander I, Astedt B (1986) Isolation of a new specific plasminogen activator inhibitor from pregnancy plasma. $\mathrm{Br} \mathrm{J}$ Haematol 62:221-228

158. Kruithof EK, Vassalli JD, Schleuning WD, Mattaliano RJ, Bachmann F (1986) Purification and characterization of a plasminogen activator inhibitor from the histiocytic lymphoma cell line U-937. J Biol Chem 261:11207-11213

159. Schleuning WD, Medcalf RL, Hession C, Rothenbühler R, Shaw A, Kruithof EK (1987) Plasminogen activator inhibitor 2: regulation of gene transcription during phorbol ester-mediated differentiation of U-937 human histiocytic lymphoma cells. Mol Cell Biol 7:4564-4567

160. Webb AC, Collins KL, Snyder SE, Alexander SJ, Rosenwasser LJ, Eddy RL, Shows TB, Auron PE (1987) Human monocyte Arg-Serpin cDNA. Sequence, chromosomal assignment, and homology to plasminogen activator-inhibitor. J Exp Med 166:77-94

161. Wohlwend A, Belin D, Vassalli JD (1987) Plasminogen activator-specific inhibitors produced by human monocytes/ macrophages. J Exp Med 165:320-339

162. Dougherty KM, Pearson JM, Yang AY, Westrick RJ, Baker MS, Ginsburg D (1999) The plasminogen activator inhibitor-2 gene is not required for normal murine development or survival. Proc Natl Acad Sci U S A 96:686-691

163. von Heijne G, Liljestrom P, Mikus P, Andersson H, Ny T (1991) The efficiency of the uncleaved secretion signal in the plasminogen activator inhibitor type 2 protein can be enhanced by point mutations that increase its hydrophobicity. J Biol Chem 266:15240-15243

164. Genton C, Kruithof EK, Schleuning WD (1987) Phorbol ester induces the biosynthesis of glycosylated and non-glycosylated plasminogen activator inhibitor 2 in high excess over urokinasetype plasminogen activator in human U-937 lymphoma cells. J Cell Biol 104:705-712

165. Belin D, Wohlwend A, Schleuning WD, Kruithof EK, Vassalli JD (1988) Facultative polypeptide translocation allows a single mRNA to encode the secreted and cytosolic forms of plasminogen activators inhibitor 2. EMBO J 8:3287-3294

166. Ye RD, Ahern SM, le Beau MM, Lebo RV, Sadler JE (1989) Structure of the gene for human plasminogen activator inhibitor2 . The nearest mammalian homologue of chicken ovalbumin. J Biol Chem 264:5495-5502

167. Samia JA, Alexander SJ, Horton KW, Auron PE, Byers MG, Shows TB Jr, Webb AC (1990) Chromosomal organization and 
localization of the human urokinase inhibitor gene: perfect structural conservation with ovalbumin. Genomics 6:159-167

168. Ye RD, Wun T-Z, Sadler JE (1987) cDNA cloning and expression in Escherichia coli of a plasminogen activator inhibitor from human placenta. J Biol Chem 262:3718-3725

169. Jensen PH, Schuler E, Woodrow G, Richardson M, Goss N, Hojrup P, Petersen TE, Rasmussen LK (1994) A unique interhelical insertion in plasminogen activator inhibitor-2 contains three glutamines, Gln83, Gln84, Gln86, essential for transglutaminase-mediated cross-linking. J Biol Chem 269:1594-1598

170. Ritchie H, Lawrie LC, Crombie PW, Mosesson MW, Booth NA (2000) Cross-linking of plasminogen activator inhibitor 2 and alpha(2)-antiplasmin to fibrin(ogen). J Biol Chem 275: 24915-24920

171. Harrop SJ, Jankova L, Coles M, Jardine D, Whittaker JS, Gould AR, Meister A, Kung GC, Mabbutt BC, Curmi PM (1999) The crystal structure of plasminogen activator 2 at $2.0 \AA$ resolution: implications for serpin function. Structure 7:43-54

172. Mikus P, Urano T, Liljestrom P, Ny T (1993) Plasminogenactivator inhibitor type 2 (PAI-2) is a spontaneously polymerizing SERPIN. Biochemical characterisation of the recombinant intracellular and extracellular forms. Eur $\mathrm{J}$ Biochem 218:1071-1082

173. Miranda E, Lomas DA (2006) Neuroserpin: a serpin to think about. Cell Mol Life Sci 63:709-722

174. Galliciotti G, Sonderegger P (2006) Neuroserpin. Front Biosci $1: 33-45$

175. Yepes M, Lawrence DA (2004) Neuroserpin: a selective inhibitor of tissue-type plasminogen activator in the central nervous system. Thromb Haemost 91:457-464

176. Hastings GA, Coleman TA, Haudenschild CC, Stefansson S, Smith EP, Barthlow R, Cherry S, Sandkvist M, Lawerence DA (1997) Neuroserpin, a brain-associated inhibitor of tissue plasminogen activator is localized primarily in neurons. J Biol Chem 272:33062-33067

177. Schrimpf SP, Bleiker AJ, Brecevic L, Kozlov SV, Berger P, Osterwalder T, Krueger SR, Schinzel A, Sonderegger P (1997) Human neuroserpin (P12): cDNA cloning and chromosomal localization to $3 \mathrm{q} 26$. Genomics 40:55-62

178. Osterwalder T, Contartese J, Stoeckli ET, Kuhn TB, Sonderegger $P$ (1996) Neuroserpin, an axonally secreted serine protease inhibitor. EMBO J 15:2944-2953
179. Yazaki M, Liepnieks JJ, Murrell JR, Takao M, Guenther B, Piccardo P, Farlow MR, Ghetti B, Benson MD (2001) Biochemical characterization of a neuroserpin variant associated with hereditary dementia. Am J Pathol 158:227-233

180. Ricagno S, Caccia S, Sorrentino G, Antonini G, Bolognesi M (2009) Human neuroserpin: structure and time-dependent inhibition. J Mol Biol 388:109-121

181. Osterwalder T, Cinelli P, Baici A, Pennella A, Krueger SR, Schrimpf SP, Meins M, Sonderegger P (1998) The axonally secreted serine protease inhibitor, neuroserpin, inhibits plasminogen activators and plasmin but not thrombin. J Biol Chem 273:2312-2321

182. Davis RL, Shrimpton AE, Holohan PD, Bradshaw C, Feiglin D, Collins GH, Sonderegger P, Kinter J, Becker LM, Lacbawan F, Krasnewich D, Muenke M, Lawrence DA, Yerby MS, Shaw CM, Gooptu P, Elliott PR, Finch JT, Carrell RW, Lomas DA (1999) Familial dementia caused by polymerization of mutant neuroserpin. Nature 401:376-379

183. Eaton DL, Baker JB (1983) Evidence that a variety of cultured cells secrete protease nexin and produce a distinct cytoplasmic serine protease-binding factor. J Cell Physiol 117:175-182

184. Scott RW, Bergman BL, Bajpai A, Hersh RT, Rodriguez H, Jones BN, Barreda C, Watts S, Baker JB (1985) Protease nexin. Properties and a modified purification procedure. J Biol Chem 260:7029-7034

185. Nick H, Hofsteenge J, Shaw E, Rovelli G, Monard D (1990) Functional sites of glia-derived nexin (GDN): importance of the site reacting with the protease. Biochemistry 29:2417-2421

186. Carter RE, Cerosaletti KM, Burkin DJ, Fournier REK, Jones C, Greenberg BD, Citron BA, Festoff BW (1995) The gene for the serpin thrombin inhibitor (P17), protease nexin I, is located on human chromosome 2q33-q35 and on syntenic regions in the mouse and sheep genomes. Genomics 27:196-199

187. DeMeo DL, Mariani TJ, Lange C, Srisuma S, Litonjua AA, Celedon JC, lake SL, Reilly JJ, Chapman HA, Mecham BH, Haley KJ, Sylvia JS, Sparrow D, Spira AE, Beane J, Pinto-Plata V, Speizer FE, Shapiro SD, Weiss S, Silverman EK (2006) The SERPINE2 gene is associated with chronic obstructive pulmonary disease. Am J Hum Genet 78:253-264 